\title{
Technological Standards, Inc.: Rethinking Cyberspace Regulatory Epistemology
}

\author{
Daniel Benoliel ${ }^{\dagger}$
}

Introduction

TABLE OF Contents

I. Technological Standardization: The Normative Framework

A. Overview

B. Types of Standardized Legal Commands ............................... 1078

1. Form Regulation: Technical Standards ........................... 1080

2. Substance Regulation: Behavioral Technological

Standards

1I. Rules v. Standards: The Anomalous Dichotomy ........................... 1087

A. Legal Standard Setting Cost Structure: The Anachronistic Equilibrium for Technological Standards

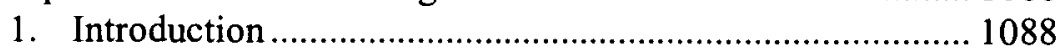

2. Fixed Costs of Promulgation............................................. 1089

a. One Shot Production Costs ........................................ 1089

i. Sunk Costs ............................................................. 1090

ii. Uncertainty Costs ................................................ 1092

iii. The Time-Cost Tradeoff........................................ I093

b. Repetitive Revision Costs .......................................... 1095

Copyright $(2004$ California Law Review, Inc. California Law Review, Inc. (CLR) is a California nonprofit corporation. CLR and the authors are solely responsible for the content of their publications.

$\dagger \quad$ J.S.D candidatc and a John M. Olin Fellow, School of Law, University of California, Berkeley (Boalt Hall). This paper was sponsored by a German Academic Exchange Service (DAAD) residential fellowship at the Graduate College for Law and Economics at the University of Hamburg, Germany. It was presented at the twentieth annual conference of the European Association of Law and Economics (EALE 2003) in Nancy, France, at the second annual conference of the Society for Economic Research on Copyright Issues (SERCl 2003) at Northampton, Massachusctts, and at the Workshop for Marie-Curie and DAAD/IQN visiting fellows and members of the Graduiertenkolleg Recht und Ökonomik, Institute for Law and Economics, University of Hamburg, Gcrmany. For their most helpful comments and support I also wish to thank Mark Lemley, Dan Rubinfeld, Hans-Bernd Schäfer, Hal Varian, Peter Menell, Dan Burk, Ken Krechmer, Eli Salzbcrger, Ben Depoorter, and the participants of all fora. For further questions or comments, please cmail mc at: daniel_b@boalthall.berkeley.edu. 
3. Variable Costs (Per Case) of Enforcement...................... 1097

a. General............................................................. 1097

b. Uncertainty Costs................................................. 1098

i. Risk Aversion Preferences ................................. 1098

ii. Frequency of Application................................. 1100

c. Irreversible Costs ................................................ 1101

B. Degree of Legal Precision...................................................... 1103

C. The Time Measurement: The Collapse of Optimal Lawmaking Back Into Ex Ante Promulgation........................................ 1106

III. Legal Process Constrictions: Exogenous Institutional Costs ......... 1108

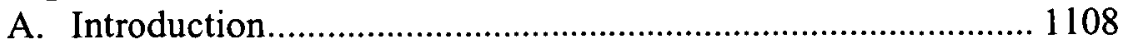

B. Decentralized Evasion of Law: Risks and Challenges............ 1112

C. Broadcast Flag System Technology: A Case Against Decentralized Manipulation of Optimal Rulemaking.............. 1113

IV. Summary and Conclusions ..................................................... 1115 


\title{
Technological Standards, Inc.: Rethinking Cyberspace Regulatory Epistemology
}

\author{
Daniel Benoliel
}

Technological standardization by the private sector (de facto) is increasingly a means of evading existing law in network environments such as cyberspace. The U.S. government, the Federal Communications Commission (FCC), and theoreticians tend to view technological standards as the digital materialization of legal standards, and, like legal standards, technological standards are also optimally designed by decentralized regulatory institutions. This paper argues, however, that emerging classes of technological standards, such as digital rights management (DRM), should be analogized to legal rules, which are centralized, rather than decentralized legal standards. It does so from a critical viewpoint of the traditional law and economics literature on optimal lawmaking, with respect to the distinction and choice between rules and standards in the legal process.

Arguably, for network environments, current developments show that technical standards are now going through a transformation from their traditional role of strictly regulating technical design of inanimate objects in the shape of legal form, to regulating behavioral performance of users in the shape of legal substance. Focusing on the latter, this paper concludes that when de facto standard setters create technological standards based on their policy preferences, rather than creating open-ended, less specific legal commands, they are turning their policy preferences into covert rules. Optimally, such rules would be created by centralized institutions.

Nonetheless, this epistemological shift to technological standards regulating behavioral performance is also met by an opposite regulatory constraint due to high standardization costs for centralized institutions. Thus, while rulemaking is optimally performed by centralized institutions, the stealthy rulemaking activity of de facto standard setters requires an adapted checks and balances approach to technological standard setting. Given these invariable institutional constraints, this paper recommends treating the regulation of technological standards, such as DRM technology, with a rule-oriented approach. 


\section{INTRODUCTION}

Technical standards, once a narrow field closely associated with state control, are rapidly evolving in network environments as a discipline of their own. In the early days of cyberspace, a decision to standardize technology typically suggested the desire to facilitate network communication through standardized communications protocols. Underlying this goal was the belief that while there would be competition in the network industry, there would be value in supporting a uniform network infrastructure. The commercialization of network environments has changed this paradigm, with the integration of standards into operational software programs. In many cases these standards began carrying normative legal substance, as their influence on user behavior expanded. One example of that front is the emerging digital rights management (DRM) technology, which prevents unauthorized use of digital works. ${ }^{1}$ This shift from technical standards, which regulate form, to standards that regulate user behavior, has significant impacts. Consequently, these new substance-based standards should carry a new name, "technological standards," to distinguish them from form-based technical standards. ${ }^{2}$

To date, the creation of such standards is over-broadly treated as standard setting, regardless of whether it addresses issues of legal form or substance. ${ }^{3}$ According to traditional law and economics analysis, standard setting decentralizes decision making by delegating more decision making

1. DRM may also be referred to as content management systems (CMS) or content/copy protection for removable media (CPRM), or sometimes as "technological measures." See discussion, infra at II.A.

2. The focaI point of this paper is the correlation between "technological standards" and Iegal rules, and the contrast between technoIogical standards and legal standards. As explained hereafter, the formal use of the terms "technical standards" or "standards" is more relevant to regulations of form than to "technological standards," which regulate user behavior. See discussion at Part I.B.1-2, respectively, infra.

3. For the U.S. government's official policy, see William J. Clinton \& Albert Gore JR, A Framework for Global Electronic COMMERCE 20-22 (July 1, 1997), http://www.technology.gov/ digeconomy/framewrk.htm (Iast visited Mar. 25, 2004) [hereinafter The 1997 Report]. The White House developed this policy with the involvement of more than a dozen federal agencies. For context applicable to DRM, see generally $i d$. at 8-11. See also SeCRETARIAT ON ELECT RONIC COMMERCE, U.S. DeP'T of Commerce, The EMERging Digital ECONOMy II §I (1999), http://www.esa.doc.gov./ pdf/EDE2report.pdf (last visited Mar. 25, 2004) [hereinafter THE EMERGING DigITAL ECONOMY II]. For a theoretical perspective, see Carl F. Cargill, Open Systems Standardization: A Business APPROACH 26-29, $137-38$ (1997), Joel R. Reidenberg, Governing Networks and Rule-Making in Cyberspace, 45 EMORY L.J. 9I I, 918, 927-28 (1996) [hereinafter Governing Networks], and Joel R. Reidenberg, Lex Informatica: The Formulation of Information Policy Rules Through Technology, 76 TEX. L. REv. 553, 570-72 (I998) [hereinafter Lex Informatica].

For an industry definition of DRM technology as standard based, see, for example, Bill Rosenblatt \& Gail Dykstra, Integrating Content Management with Digital Rights Management Imperatives and Opportunities for Digital Content Lifecycles (2003) (White Paper), http://www.xrml.org/reference/cmdrmwhitepaper.pdf. See also discussion infra Part I.B.I. 
power to sublevels of the legal system. ${ }^{4}$ Policy makers and commentators generally assume this trend also takes place in network environments, such as the Internet. ${ }^{5}$ The formal technological standardization policy in the United States takes a strong, albeit imprecise, position against government centralization of standard setting in network environments and does not distinguish enough between different types of standards, primarily infrastructure and application standards. ${ }^{6}$ Rather, the government's stance is that decentralized industry standardization organizations (gray) and, in some cases, private sector (de facto) standard setters should set technological standards for the Internet. ${ }^{7}$

Arguably, with the materialization of advanced technological standards that regulate user behavior, instead of merely regulating form, the underlying assumption that such technological standards are or should be

4. See, e.g., Isaac Ehrlich \& Richard A. Posner, An Economic Analysis of Legal Rulemaking, 3 J. Legal Stud. 257, 267 (1974); see also discussion infra Part ll1.A.

5. For the U.S. government's official policy, see Telecommunications Act of 1996, 47 U.S.C. $\S$ 230(b)(2) (1998) (stating that the FCC has a responsibility to implement the statute and "[i]t is the policy of the United States ... to preserve the vibrant and competitive free market that presently exists for the Internet and other interactive computer services, unfettered by Federal or State regulation") and The 1997 Report, supra note 3, at 20 ("The United States believes that the markctplace, not governments, should determine technical standards and other mechanisms for interoperability.").

For the context of DRM teehnology, see The 1997 Report, supra note 3, at 9 ("The U.S. Government recognizes private sector efforts to develop international and domestic standards in [the areas of] ... copyright management information and technological proteetion measures."). See also National Technology Transfer and Advancement Aet of 1995, Pub. L. No. 104-113, § 2(3), 10 Stat. 775 (1996) (codified as amended at 15 U.S.C. $\S 3701$ (1996)) [hereinafter NTTAA] ("The commercialization of teehnology and industrial innovation in the United States will be enhanced [by] companies."); The Emerging Digital Economy I, supra note 3, at 3-7.

For a theoretical perspective, see, for example, Lawrence Lessig, Code and OTHer LAws of CyberspaCe 35-36 (I999), Mark A. Lemley, Standardizing Government Standard-Setting Policy for Electronic Commerce, I4 BERKELEY TECH. L.J. 745, 748 (criticizing the U.S. government for dictating an encryption standardization policy), Lex Informatica, supra note 3, at 570-72, 589-92, and Edward L. Rubin, Computer Languages as Networks and Power Structures: Governing the Development of XML, 53 SMU L. REv. 1447, 1455 (2000) (concluding that, at present, the government does not want to undertake the task, private groups do not want government intrusion, and no one thinks government will develop the optimal standards).

6. See The 1997 Report, supra note 3, at 20 ("The United States considers it unwise and unneeessary for governments to mandate standards for electronic commerce."). The 1997 Report also refers to eentralized govcrnment control over standards development as a "[p]otential area[] of problematic regulation." $I d$. at 2; see also Daniel Benoliel, Cyberspace Technological Standardization: An Institutional Theory Retrospective, 18 BERKELEY TECH. L.J. I259 (2003) (supporting separate institutional policies for infrastructure and application standard setting in cyberspace).

7. See The 1997 Report, supra note 3, at 20 ("[W]e urge industry driven multilateral fora to consider technical standards in this area."). Nevertheless, The 1997 Report states that "[i]n some eases, multiple standards will compete for marketplace acceptanee." Id. at 21 . In support of private sector intervention, the U.S. Government Working Group on Electronic Commerce published a report containing a resolution advoeated at the Global Standards Conference in 1997, in which government participants agreed to let the private sector lead in standard-setting. THE U.S. Gov'T WORKING GrouP on Electronic Commerce, First Annual Report IV (Nov. 1998), http://www.doc.gov/ecommerce/ E-comm.pdf (last visited Mar. 6, 2004). 
conceptualized as legal standards instead of legal rules is to a large degree false. Conceptually, this transformation of technological commands also seems to comply with an extension of the traditional law and economics common law hypothesis: in a perfect world, the ex post application of legal standards should approximate the legal rules that regulators would have chosen in an ex ante choice of law. In such conditions, standard setting emulates rulemaking, and what are otherwise thought to be optimally designed legal standards are, in fact, stealthy legal rules. Accordingly, due to the techno-economical developments network technology is going through, programmable commands, such as the content scramble system (CSS), which provides anti-copying protection for encrypted DVD technology and other DRM technologies, are wrongly considered "technical standards." Unlike traditional "technical standards," which only regulate form, however, these standards regulate user behavior and have the characteristics of legal rules.

Immediate institutional implications flow from this conclusion. According to traditional optimal lawmaking theory, legal rules are best made by centralized institutions, such as the government. ${ }^{8}$ However, in constantly evolving network environments like the Internet, centralized regulation is inefficient and cannot keep pace with their dynamic, commercialized nature. ${ }^{9}$

In essence, two contradicting developments seem to be occurring in tandem, creating a regulatory anomaly. On the one hand, cyberspace's technological standards regulating the use of digital content are becoming increasingly widespread and pervasive and are analogous with legal rules, thus suggesting they should be created centrally. On the other hand, it is decentralized regulation, associated more with legal standards than rules, that is the dominant institutional source of technological standard setting. Given the nature of the technology involved, both trends seem to be irreversible. In theory and in practice, this emerging regulatory tension primarily necessitates adoption of a system of checks and balances vis-à-vis decentralized technological standard setters. Such an approach uItimately should ensure that the decentralized process through which technological standards are designed remains attentive to the democratic decision-making procedures and the social values that centralized regulatory regimes are designed to uphold.

This anomaly has far-reaching implications that also necessitate further regulatory change. Issues concerning screening policies of private standardization, the legal relations between legislative bodies and governmental agencies, and the interplay between market (de facto), industry (gray), and formal (de jure) standardization organizations are all

\footnotetext{
8. See discussion infra Part III.A.

9. See discussion infra Part III.A.
} 
significantly intertwined with the ability of legal systems to design legal commands.

Leaving these important implications to further research, I purport to explain the current incongruity of technological standardization. Part 1 describes the normative framework in which technological standardization is taking place. Standards regulate legal form when they define specific value measurements such as quality, quantity, and service. In the early days of cyberspace, standardized protocols were largely form regulation, because they were strictly designed to transfer user data and control by specifying a uniform physical or metric design of the Internet's core infrastructure. As network environments became commercialized, standards shifted from merely regulating form to an emerging class of technological standards that regulate substance in a legally binding manner. Because technological standards control user behavior, they may supplement or even supplant competing legal rule sets. As a tool that functions as a legal command, technological standards should be subject to the law and economics rulestandard distinction.

Part II pursues this rule-standard distinction on three levels. First, it evaluates technological standards under the model suggested by Louis Kaplow, which describes the dichotomy between rules and standards as a product of the tension between two types of costs: costs associated with fixed promulgation of legal commands and the variable costs (per case) of enforcing them. Legal standards are said to have low fixed costs of command specification and high costs (per case) of adjudication. Legal rules, on the other hand, entail high costs for command specification but low costs for adjudication. Similarly, technological standards tend to have high initial promulgation costs relative to legal standards, but lower enforcement costs. In the promulgation stage they carry sunk costs that cannot be recovered if the enacted command proves to be ineffective or undesirable at a later time. They also carry uncertainty costs of high investment risks that result from the trial and error processes of manufacturing. With regard to enforcement, technical standards suggest low costs associated with both the level of adaptation to the preferences of risk-averse users of such technology and the frequency of individual application and adjudication of such commands. These factors suggest technological standard setting is more similar to rulemaking than standard setting.

Second, Part II analyzes the correlation between the degree of legal precision and the ex post evaluation of the choice between the two legal commands. Following Isaac Ehrlich and Richard Posner's seminal model, optimal lawmaking analysis suggests that increased regulatory precision decreases the number of standards required. A fundamental implication of this analysis is that any exogenous effect that increases the benefits or reduces the costs of legal precision, other things remaining the same, will 
increase the optimum number of rules. This Part argues that technological advances in network environments should redefine technological standards and acknowledge their rule-oriented cost structure even before designers choose between rules and standards. Relying on this framework, this Part then examines technological standards through three indicators for the increasing degree of precision model: the varying degree of over- and underinclusive design of rules relative to standards, the variable degree of nonintuitiveness of rules, and the constant indicator for syllogistic deductive reasoning. As will be shown, all three suggest that technological standards behave like rules.

The third ingredient of optimal lawmaking in law and economics analysis is the optimal timing of the lawmaking cost evaluation. Standards and rules may be ex ante in nature, as they may apply before, or at least independently of, the occurrence of harm. Alternatively, they may be ex post in nature, as they may be triggered only by the occurrence of harm. Timely regulation may prevent irreversible losses, and benefits of timeliness may offset, to some degree, the sunk cost of legal intervention.

Through technological standard setting, many of these later estimations can be done ex ante, as they define the standard's value measurements themselves. Consequently, in this new technological realm, there are typically few advantages to delaying investments because it will be easier to acquire information when individuals act or cases are adjudicated. As a result, the ex post costs associated with uncertainty and irreversibility of enforcement of technological standards can be integrated into the ex ante cost structure and decision-making discretion. Technological standard setting is, arguably, substantively less constrained by the value of waiting per se.

Along with these internal constraints on the choice between rules and standards there is an external constraint of institutional administration costs. These constraints apply to any choices, beyond the regulatory production process itself, as will be explained in Part III. This Part begins by explaining the law and economics theory that legal standards decentralize decision making while legal rules tend to centralize it. This distinction does not apply to the lawmaking dynamics of technology because today's technology limits the ability of centralized institutions, such as governments, to program and design technological standards efficiently. Therefore, technological standards are bound to remain institutionally autonomous and decentralized.

However, without the democratic decision-making mechanisms, and the pre-commitment to social values of centralized law-making institutions, decentralized profit-maximizing standard setters may direct technological design to evade the law. Such is the case whenever excessive private allocation of rights to information is precariously tolerated and facilitated by 
public lawmakers. For example, the impending introduction of unencrypted digital television broadcasting DRM technology threatens the public access doctrine of fair use.

Part IV describes scveral policy rationales underlying technological standardization. Primarily, it concludes that whenever the emerging private sector (de facto) standard setters in network environments are unwilling to withdraw their policy preferences into open-ended, general, and less specific commands, they are turning them into covert rules. In essence, technological standards, like rules, influence behavior directly. Like rules, technological standards may now be normative, contextual, direct, and enforcement enabling. Consequently, the Federal Communication Commission (FCC) should carefully balance the rulemaking process of technological standard setting.

\section{I}

\section{Technological Standardization: The Normative Framework}

\section{A. Overview}

In network environments, the term "standard" is largely understood to mean uniform physical and design specifications or metrics. ${ }^{10}$ Like its predecessor, the legal standard, the technical standard regulates form. The infrastructure of cybcrspace, for example, is defined by a unified architectural structure and standardized protocols, collectively known as the formal TCP/IP networking reference model." Technical standards do not raise scrious normative issues, because they are concerned only with the form and value measurements of the Internet's infrastructure, such as quality assurances, bit size, and attached transit services.

With the evolution of standard setting from technical to "technological" standards, that truth is no longer categorical. While technical standards regulate form, technological standards more directly regulate user behavior. Such technological standards embed normative choices set

10. See James J. Anton \& Dennis A. Yao, Standard-Setting Consortia, Antitrust, and HighTechnology Industries, 64 ANTITRUST L.J. 247, 248 (1995) ("[M]ost of the precedent applicable to standard-setting organizations comes from experience with the setting of technical quality and safety standards."); Margaret Jane Radin, Online Standardization and the Integration of Text and Machine, 70 FORDHAM L. REv. 1125,1127 (2002); see also International Organization for Standardization (1SO), at $\mathrm{http}: / / \mathrm{www}$.iso.org/iso/en/aboutiso/introduction/index.html (last modified Feb. 16, 2004). ISO is the world's largest developer of standards, and its prineipal activity is the development of teehnical standards. See id. Not all standards, either in network environments or beyond, are technically oriented. Instead, they can be designed generally, as legal behavioral standards, as principles, or as social goals. See discussion infra Part ll.B.

11. See, e.g., Hans-Werner Braun \& K. Claffy, Network Analysis for a Public Internet, in Public ACCess to THe INTERnet 353-56 (Brian Kahin \& James Keller eds., 1995); $c f$. CRAIG Hunt, TCP/IP Network Administration 1-22, 6, 8-9 (2d ed. 1997) (describing the TCP/IP networking reference model in four levels: (1) "network access," (2) "Internet," (3) "host-to-host transport," and (4) "applications"). 
by program designers. ${ }^{12}$ When technological products are standardized, firms may manipulate such standards for competitive or other advantages. ${ }^{13}$ Thus, technological standards, like other delineated legal entitlements of property, may overprotect the creation and recognition of property rights in intellectual goods. ${ }^{14}$

Technological designs, such as digital rights management (DRM), can be understood as a form of policy making that may supplement or even supplant legal rules governing behavior. ${ }^{15}$ Once constraints on behavior are built into technology, the technological standards established by the constraints effectively govern use of that technology in a manner that competes with law. ${ }^{16}$ Technological standards may be seen as equivalent to a licensing regime ${ }^{17}$ or as a form of copyright law. ${ }^{18}$ In some cases, technological standards can be more anticompetitive than legal rules and may give rise to antitrust concerns. ${ }^{19}$ From an institutional standpoint, the legal challenges created by standardized technology are present not only when firms standardize technology themselves but also when governments do so. ${ }^{20}$ Because technological standards act as law, they should be subjected to an optimal lawmaking analysis.

\section{B. Types of Standardized Legal Commands}

Normative legal commands, rules and standards, can be broken into two categories. ${ }^{21}$ First, legal commands may regulate form, such as the

12. See Niva Elkin-Koren, Copyrights in Cyberspace - Rights Without Laws?, 73 CHI-KENT L. Rev. 1155, 1186 (1998); Lawrence Lessig, Constitution and Code, 27 CumB. L. Rev. 1, 14 (1997); Lawrence Lessig, The Constitution of Code: Limitations on Choice-Based Critiques of Cyberspace Regulation, 5 CommLaw Conspectus 181, 184 (1997); Governing Networks, supra note 3, at 918, 927-28; Joel R. Reidenberg, Rules of the Road for Global Electronic Highways: Merging the Trade and Technical Paradigms, 6 HARV. J.L. \& TECH. 287, 301-04 (1993).

13. Stanley M. Besen \& Joseph Farrell, Choosing How to Compete: Strategies and Tactics in Standardization, 8 J. ECON. PERSP. 117, 117-18 (1994) (asserting that firms manipulate standards for competitive advantage).

14. See Dan L. Burk \& Julie E. Cohen, Fair Use Infrastructure for Rights Management Systems, 15 HaRv. J.L. \& TeCh. 41, 52 (2001); Deirdre K. Mulligan, Introduction: Digital Rights Management and Fair Use by Design, 46 Communications of the ACM (CACM) 30-33 (April 2003).

15. Burk \& Cohen, supra note 14, at 50; Lex Informatica, supra note 3, at 568-76.

16. Burk \& Cohen, supra note 14, at 50; Lex Informatica, supra note 3, at 568-76.

17. See Burk \& Cohen, supra note 14, at 51-52; see also Julie E. Cohen, Copyright and the Jurisprudence of Self-Help, 13 BERKELEY TECH. L.J. 1089, 1140-42 (1998).

18. See Burk \& Cohen, supra note 14, at 54-59.

19. See, e.g., David J. Teece \& Edward F. Sherry, Standard Setting and Antitrust, 87 MiNN. L. REv. 1913 (2003) (suggesting that technological standards should be restricted even more than rules).

20. See Lemley, supra note 5, at 748-750 (criticizing the U.S. government for dictating an encryption policy); see also Lessig, supra note 12, at 35-36 (criticizing governmental code control of the use of encryption in cyberspace).

21. See, e.g., H. L. A. HART, The Concept of LAW 130-31 (1961); Ehrlich \& Posner, supra note 4, at 258; Louis Kaplow, Rules Versus Standards: An Economic Analysis, 42 DuKE L.J. 557, 618 (1992); Duncan Kennedy, Form and Substance in Private Law Adjudication, 89 Harv. L. REv. 1685, 1697-701 (1976). 
requirements to obtain a drivers' license. The second category of legal commands regulates substance. These commands can be either default or binding. Default commands (ius dispositivum) are voluntary and are only binding when no other binding, nonvoluntary command applies instead. Default legal rules include, for example, the contractual remedies available when parties fail to specify a remedy, and default legal standards include the principles of fairness, due care, reasonableness, and good faith. The second type of substantive legal command is the binding command (ius cogens), which is designed by the government to prevent harm-producing behavior and is nonvoluntary. An example of a binding legal rule is the prohibition on access by minors to websites containing adult materials. The strict liability absolute duty of care is an example of a binding legal standard.

In network environments, many legal commands no longer merely regulate form and instead are better classified as binding commands that regulate user behavior. An example of a technologically designed legal command that regulates user behavior is the standardized serial copy management system, which permits record companies to control digital copying of recorded music. In essence, it supports standardized digital equipment containing legally mandated features. This system is at the heart of the Audio Home Recording Aet of 1992, which requires digital copying recorders to be equipped with standardized circuitry that prevents them from being used to make serial copies (copies of copies) of digital recordings. ${ }^{22}$

This paper focuses on legal commands that regulate substance, and specifically on the subcategory of binding commands (ius cogens) regulating harm-producing behavior. Whenever such commands are designed as rules, they are typically designed in an all or nothing fashion. ${ }^{23}$ When the facts a rule stipulates are given, the rule either applies and is mandating or irrelevant to the legal analysis and decision at issue. ${ }^{24}$ Alternatively, when such binding substantive commands are designed as standards, they are not all or nothing. Instead, standards typically refer to one of the substantive objectives of the legal order, stipulated as a general principle or goal of social action. ${ }^{25}$ Accordingly, the standard's application requires judicial ex

22. 17 U.S.C. $\$ 1002$ (2001). MP3 technology for storing recorded music and consumers' use of computers nevertheless undercut the Serial Copy Management System, because computers, as defined by the Copyright Act, $\S 1001(5)(B)$ (ii), are exempt from the requirement of having anticopying circuitry. See also Recording Indus. Ass'n of Am. v. Diamond Multimedia Sys., Inc., 180 F.3d 1072 (9th Cir. 1999); Lionel S. Sobel, DRM as an Enabler of Business Models: ISPs as Digital Retailers, 18 BERKELEY TECH. L.J. 667, 676 (2003).

23. See Ronald M. Dworkin, The Model of Rules, 35 U. CHI. L. Rev. 14, 25 (1967).

24. See id.

25. See, e.g., id. at 22,25 (referring to standards that operate as principles that do not set clear legal consequences); Ehrlich \& Posner, supra note 4, at 270 (same); Kennedy, supra note 21, at 1688. 
post intervention in the discovery of both the particular facts of the case and their legal evaluation under the standard. ${ }^{26}$

Regulators can choose whether to regulate with rules or standards. A regulator may use a standard, and thus give greater discretion to the enforcement authority, or a regulator may choose to use a rule to specify the particular outcome. Technological standards have more in common with legal rules and do not fit neatly into the category of standards. Like rules, they regulate user behavior, in contrast to technical standards, which merely regulate form.

\section{Form Regulation: Technical Standards}

When legal commands that regulate form are promoted through legal rules, they are characterized by a high level of specificity backed by an authoritative executing mechanism that leaves little room for judicial discretion. Such are many of the rules regulating civil and criminal procedural law. When commands are designed as legal standards, they are typically characterized by the level of the technical value measurements such as the quantity, weight, extent or quality they provide. ${ }^{27}$

In network environments, such as cyberspace, the term "technical standards" generally means uniform physical and design specifications or metrics and, as such, technical standards are regulations of form. ${ }^{28}$ The U.S. government's definition of "technical standards" as performancebased or design-specific technical specifications and management system practices is articulated in the National Technology Transfer and Advancement Act of I995 (NTTAA). ${ }^{29}$ The President's Office of Management and Budget (OMB) elaborated on this definition in the Revised OMB Circular No. A-119, "Federal Participation in the Development and Use of Voluntary Consensus Standards and in Conformity Assessment Activities" ("the Circular"). ${ }^{30}$ The Circular defines "standard" and "technical standard" narrowly as "a common and repeated use of rules, conditions, guidelines or characteristics" that serves to measure products, related processes, and production methods. ${ }^{31}$

26. See, e.g., Kennedy, supra note 21 , at 1688 .

27. See Kaplow, supra note 21, at 559 (citing Webster's New Collegiate Dictionary at 1133 (1977))

28. Radin, supra note 10 , at 1127

29. Pub. L. No. 104-113, 110 Stat. $775 \S 12(d)(4)$ (1996) (codified as amended in scattered sections of 15 U.S.C.) [hereinafter NTTAA1.

30. 63 Fed. Reg. 8546-01 (Office of Mgmt. \& Budget Feb. 19, 1998) [hereinafter the Circular]. This Circular replaced Cireular A-119, Federal Participation in the Development and Use of Voluntary Standards, 54 Fed. Reg. 57645 (Oct. 20, 1993). The OMB issued this revision of the Circular in order to improve the internal management of the Executive Branch. Consistent with section 12(d) of the NTTAA, section 1 of the Circular directs agencies to use voluntary consensus standards in lieu of government standards exeept where inconsistent with law or otherwise impractical.

31. See the Circular, supra note 30 , at $\$ 3(a)$. 
Consistent with the NTTAA's and the Circular's narrow definition of a technical standard as a regulation of form, section 3(c) of the Act further distinguishes between two types of formal technical standards: "performance standards" and "prescriptive standards." 32 Like performance standards in the physical world, which specify the performance levels goods must achieve, but otherwise leave discretion to firms who implement them, ${ }^{33}$ a performance standard under the NTTAA requires specific results but does not state methods for achieving those results. ${ }^{34}$

Similarly, like the early "design standards" of the physical world, which specify particular features that goods must have to conform with the standard, ${ }^{35}$ a "prescriptive standard" may specify design requirements, such as the materials to be used, how a requirement is to be fulfilled, or how an item is to be fabricated or constructed. ${ }^{36}$ The Circular also provides a list of value measurements a technical standard can measure, including quantity measurements, ${ }^{37}$ quality, ${ }^{38}$ and other dimensions. ${ }^{39}$

Formal technical standards have evolved through three categories that together define the scope of technical standards: "representational standards," "unit standards," and "similarity standards." standards, the most basic class of technical standards, define abstract quantities. Examples of representational standards are the number system, addresses, currency, and mathematical notation, such as +, -, and \%. They are arbitrary human constructs without a corresponding physical representation. Unit standards define physical quantities, such as meters, miles, grams, volts, and seconds. ${ }^{41}$ Occasionally, these two categories of

\footnotetext{
32. Id. $\S 3(\mathrm{c})$.

33. See Stephen BReyer, Regulation And Its Reform 105-06 (1982).

34. See the Circular, supra note 30 , at $\$ 3(\mathrm{c})$.

35. See BREYER, supra note 33, at 105-06.

36. The Circular, supra note $30, \S 3(\mathrm{c})$.

37. See id. $\S 3(\mathrm{a})(2)$

38. See id.

39. For other value measurements, see id. ("The definition of terms; classification of components; delineation of procedures; specification of dimensions, materials, performance, designs, or operations; measurement of quality and quantity in describing materials, processes, products, systems, services, or practices; test methods and sampling procedures; or descriptions of fit and measurements of size or strength.").

40. Ken Krechmer, The Fundamental Nature of Standards: Technical Perspective, IEEE COMm. MAG., June 2000 , at 70 . Together, these three terms comprise the definition of "technical standards" used herein. For alternative overlapping categorization schemes, see, for example, Paul A. David, Some New Standards for the Economics of Standardization in the Information Age, in ECONOMIC POLICY AND Technological Performance 211-17 (Partha Dasgupta \& Paul Stoneman eds., 1987). As David reminds us, the American Society for Testing and Materials has recognized five categories of standards depending on the information conveyed: definitions, classifications, practices, test methods, and specifications. Id. See also David Hemenway, Industrywide Voluntary Product Standards 87

41. For a historical overview, see A. E. Berriman, Historical Metrology (1953) (providing a summary of weights and measures from the earliest times to about 1900); BRUNO KISCH, SCALES AND
} (1975). 
standards are combined. Human language is such a case, as it is based on specific sounds made by the human voice. ${ }^{42}$ In network environments, unit standards include the Open System Interconnect (OSI) reference model of the Internet's architecture, and the American Standard Code for Information Interchange (ASCII) character set, the most common standard for the I28 code numbers used by computers to represent all upper- and lowercase Latin letters, numbers, and punctuation.

Lastly, similarity standards are groupings of specific unit and representational standards that define the common physical properties of two or more entities, usually to provide some interchangeability in manufacturing, distribution, sales, and use. Examples include: no. 2 pencil quality, A4 paper size, the Scholastic Aptitude Test (SAT) evaluation procedure, and the ISO 9000 quality standard process definition. ${ }^{43}$ A proper similarity standard is closed, such that the standard predefines any possible variations in form. Similarity standards were essential to the industrial revolution; they describe the results of repetitive and fixed processes made to decrease production costs, and their complexity is multi-dimensional. ${ }^{44}$

In network environments, many communication standards, especially protocol standards, behave like similarity standards. ${ }^{45}$ They define transmitting and receiving pairs, process definitions, and even quality test procedures. An example of a similarity standard in a network environment is the industry standard for information systems, the Internet ISO/IEC 15288 "Life Cycle Management-System Life Cycle Processes." 15288 establishes a common cyclical production process of system technologies, such as the Internet, describing their technical value measurements and associated terminology. ${ }^{47}$

Weights: A Historical Outline (1965) (providing a comprehensive study on weighing and its instruments from the ancient world to modern times).

42. Language, like technical standards, utilizes increasing levels of segmentation to transfer information. See Ludwig Wittgenstein, Philosophical Investigations §§ 256-81 (G.E.M. Anscombe trans., Oxford 1968).

43. See Ken Krechmer \& Elaine Baskin, Standards, Information and Communications, at http://www.csrstds.com/siit2001.html; see also David, supra note 40, at 216

44. See, e.g., David, supra note 40, at 216; see also Brian W. Arthur, Self-Reinforcing Mechanisms in Economics, in The Economy as an Evolving Complex System 9 (Addison Wesley ed. 1988) (further identifying similarity standards per their ability to minimize production costs and increase learning effects of their users).

45. In information technology, protocols are often described in an industry or international standard, and are the special set of specifications that end points in a telecommunication connection usc when they communicate. See, e.g., whatis.com (for 'Protocol'), at http:// scarchnetworking.techtarget.com/sDefinition/0,sid7_gci212839,00.html (last visited March 26, 2004).

46. http://www.15288.com (last visited Mar. 25, 2004); see also Software Productivity Consortium, ISO/IEC 15288, at http://www.software.org/quagmire/descriptions/iso-iec15288.asp (last visited Mar. 25, 2004).

47. See Dictionary of Software, ISO/IEC 15288, at http://www.esi.es/Help/Dictionary/ Definitions/ISO-IEC_15288.html (last visited Mar. 6, 2004); see also 1SO/lEC 19760-Guide for 
Standards that regulate formal value measurement specifications are not unique to cyberspace. They existed in earlier information technology industries, particularly mobile telephony, high definition television (HDTV), and the radio frequency spectrum. ${ }^{48}$ Ultimately, the correlation between standards and form regulation was imported into the emerging governance of cyberspace. Primarily, the Department of Commerce limited the authority of the Internet Corporation for Assigned Names and Numbers (ICANN), which controls the Internet's domain name system, to "technical coordination" or routine "maintenance." ity, ICANN controls technical issues such as the maintenance of the bit size of data packets, the architecture of root services (which involves assigning Internet protocol (IP) numbers and specifying the number of top level domains that safely be added to the root), and the preservation of unique protocol numbers for various other Internet functions. ${ }^{50}$ Thus, the U.S. government authorized ICANN solely to construct technical standards aimed at regulating form, but did not give ICANN any authority to regulate user behavior. Nevertheless, this policy is not fully exhaustive or consistent, though, as both types of standards secm to be loosely merged in the 1997 Report. $^{51}$

As demonstrated by the NTTAA, the Circular, and the limited authority given to the ICANN, the U.S. government has not recognized the possibility that technical standards might also regulatc substance, and might, therefore, require a separate institutional policy. It is this separate class of

ISO/IEC 15288 (System Life Cycle Processes), a guide to ISO/1EC 15288 (Feb. 2003) at http://www.techstreet.com/cgi-bin/detail?product id=1141885.

48. For the International Telecommunication Union (ITU) experience, see The ITU Telccommunication Standardization Sector (1TU-T), at http://www.itu.int/ITU-T/. For a historical account of the restructuring of the ITU in 1947 up to the 1980s commercialization of telecommunications information for the "technical" organs, including the Administrative Radio Conferences (ARC) and the International Frequency Registration Board (IFRB). See KeLLEY LEE, Global Telecommunications Regulation: A Political Economy Perspective 131-33 (1996); see also David, supra note 40, at 206-07.

49. See Management of Internet Names and Addresses, 63 Fed. Reg. 31,741, 31,744 (Nat'l Tclecomms. \& Info. Admin. June 10, 1998). Starting in early 1998, IANA at USC/ISI began publishing what would amount to fivc successive vcrsions of a plan for an organization that would cventually becomc ICANN. See Memorandum of Understanding Between the U.S. Department of Commerce and Internet Corporation For Assigned Names And Numbers (November 25, 1998), http://www.ntia.doc.gov/ntiahome/domainname/icann-mcmorandum.htm.

50. Id. Cf. National Telecommunications and Information Administration, Dep't of Commerce, A Proposal to Improve Technical Management of 1NTERnet and Addresses (1998) (Detailing ICANN's earlier technical standardization mandate (The Green Paper)).

51. Two inconsistencies of standards that are able to regulate substance are found in section II.4. of The 1997 Report, which references under the title "Intellectual Property," regarding "technological protection" and "copyright management information standards" the narrow definition of "technical standards" found in section 9. See The 1997 Report, supra note 3, at $\S 9$; see also THE EMERGING Digital. ECONOMY 11, supra note $3, \S 1$. 
substantive standards, referred to here as "technological standards," that is the focal point of this paper. ${ }^{52}$

\section{Substance Regulation: Behavioral Technological Standards}

In the information age, technical standards have increasingly been incorporated into operational software designs that influence user behavior. Ultimately, the design process of these standards started to resemble the design process of software programs containing mandatory legal commands. ${ }^{53}$ Thus, technological standards became an aspect of software design and standard developers became closely related to programmcrs. ${ }^{54}$ To illustrate, when a specific software program is used as a test bed, the specific program in the test bed takes on the characteristics of a technological standard, implementing the information it contains.

This shift is particularly evident with the development of DRM. As new markets and submarkets in network environments expand, businesses are experimenting with distribution models, such as dynamic pricing, permission to view content in exchange for user demographics, and syndication of content to other websites. ${ }^{55}$ One of the most controversial of these developments is DRM technology developed by copyright-driven industries. DRM software prevents purchasers and third parties from making unauthorized uses of digital works. ${ }^{56} \mathrm{DRM}$ technology has two separate

52. Regarding DRM technology, see The 1997 Report, supra note 3, at 9 ("The U.S. Government recognizes private scctor efforts to develop international and domestic standards in [the areas of] ... copyright management information and technological protection mcasures."). See also THE Emerging Digital Economy II, supra notc 3, at §1.

53. Radin, supra note 10, at 1138; Krechmer, supra note 40, at 70.

54. See Ken Krechmer, Cathedrals, Libraries and Bazaars, Remarks at the Association of Computing Machinery (ACM) Symposium on Applied Computing Meeting (Mar. 10-13, 2002) (suggesting that the production processes of standards and of commercial software are becoming closely related and extracting ten lessons that may apply to both standards development and software program development), at http://www.csrstds.com/cathedrals.html (last visited Mar. 25, 2004).

55. See generally GiantSteps Media Technology Strategies, Digital Rights Managcment: Technology and Solutions (June 2000), at http://www.giantstepsmts.com/drmarticle.htm (last visited Mar. 25, 2004) (describing generally DRM content distribution models).

56. DRM technology is mentioned in the WIPO Copyright Treaty of 1996. WIPO Copyright Treaty, Apr. 12, 1997, arts. 11-12, S. Treaty Doc. No. 105-17, 36 I.L.M. 65, 71-72 (adopted Dec. 20, 1996), available at http://wipo.int/clca/docs/en/wo/wo033en.htm\#P88_11974 (last visited Mar. 25, 2004). The treaty refers to DRM as "technological measures" used in the restriction of unauthorized acts in copyrighted works of art, and it also refers to this technology as "rights management information" used to identify rights holders, authors, and the terms of authorized use. Id. art. 12,36 I.L.M. 72. In addition, the Treaty requires adhering nations to protect both national and foreign authors through domestic law. Id. $\S 5.3$. Forty six nations have become parties to the WIPO Copyright Treaty. WIPO Copyright Treaty Contracting Parties, available at http://www.wipo.int/treaties/en/ documents/pdf/s-wct.pdf. See also WIPO Performance and Phonograms Treaty, Dec. 20, 1996, S. Treaty Doc. No. 1051-17, 36 I.L.M. 76, available at http://www.wipo.int/cdocs/trtdocs/en/ wo/wo034en.htm; Agreement on Tradc Rclated Aspects of Intellectual Property Rights, April 15, 1994, Marrakcsh Agreement Establishing the World Tradc Organization, Annex IC, 33 I.L.M. 1197; Berne Convention for the Protection of Literary and Artistic Works, Sept. 6, 1886, art. 5(2), 25 U.S.T. 1341, 828 U.N.T.S. 221 (amended Sept. 28, 1979). 
functions. First, it identifies digital versions of copyrighted works, just as international standard book numbers (ISBN) identify hardcopy books and stock keeping unit (SKU) numbers identify retail merchandise. ${ }^{57}$ Copyright owners use two main types of existing technologies, known as "watermarking" 58 and "fingerprinting," 59 to create digital identifications for their works. The identification function tracks works electronically, such as when they are transmitted over basic peer-to-peer networks in the form of email or instant message attachments.

Second, DRM software may also provide copyright owners with control over the various excludable rights of copyright ownership, including access to their works and the ability to make copies of and redistribute the works. At the heart of any DRM technology is the business notion of a rights model: a scheme for stipulating to users rights to a portion of content in return for consideration, such as registration, payment, or consent to the tracking of his or her usage.$^{60}$ Alternatively, many networks have architectural designs and technological standards that implement the norm of open information access.

There are two new types of technological standards specific to network environments: "compatibility standards" and "adaptive standards." Compatibility standards specify a grouping of similarity standards to support local or remote communications between independent implementations. Examples of compatibility standards include X.25, which governs packet communications, and EIA-232, which provides a standard serial digital interface. ${ }^{62}$ When properly written, compatibility standards do not force all implementations to be similar, as long as they support compatible interchange of information through different interfaces. This allows

57. For a description of digital object identification (DOI) technologies for identifying content objects, see generally, The Digital Object Identifier System, at http://www.doi.org (last updated Mar. 22, 2004).

58. Watermarking involves digital identifications inserted into each digital copy of a work at the time it is manufactured. "Watermarks" are data added to the digital file that make a small change, usually unnoticed by the user. See Commission Staff Working Paper on Digital Rights: Background, Systems, Assessment, SEC (2002) 197, at 19, available at http://www.politechbot.eom/docs european.commission.drm.030202.pdf (Iast visited Mar. 25, 2004) [hereinafter EC Digital Rights Working Paper].

59. Fingerprinting involves digital identifications inserted into unwatermarked content of digital copies after their manufacture. Fingerprinting converts unwatermarked works into unique digital identification marks. See, e.g., Nevin Heintze, Scalable Document Fingerprinting (Extended Abstract), at http://www-2.cs.cmu.edu/afs/es/user/nch/www/koala/main.html (last visited May 25, 2004).

60. See GiantSteps Media Technology Strategies, supra note 55.

6I. Krechmer, supra note 40 , at 72 at fig. 1 and accompanying text.

62. As Krechmer explains, the previous three successions of standards are forms of source coding. Id. Compatibility standards, as they define a channel, define the channel coding. Id. 
standard designers or programmers to manipulate compatibility standards to meet their preferences. ${ }^{63}$

Adaptive standards are open-ended, and allow the specification of areas left open for future revisions, manufacturer-specific options, and further study. They specify a negotiation process concerning the exchange of data between separate technological systems that includes two or more compatibility standards, and are used to establish communications. ${ }^{64}$ The ability of users to access usenet, ftp, or www on the Internet is such a form of negotiation. Examples of adaptive standards are the IETF Internet draft 11 and the protocol extension protocol, which are designed to accommodate extensions of applications such as hyper text transfer protocol (HTTP) clients, servers and proxies. ${ }^{65}$ Adaptive standards allow each compatibility standard to negotiate a range of variables, including quality of communication, quantity of data transmitted, and other parameters of these systems. Thus, when protocols are open ended by design and are used for negotiation instead of nonnegotiable incompatible transfer of user data and control, they may be considered adaptive standards. Because of the widespread use of programmable processors and the similarity to sophisticated software programs, adaptive standards are becoming increasingly important both technologically and as a mechanism to regulate user behavior ${ }^{66}$

Technological standards provide the means to implement legal proprietary functions, such as copyright excludable rights, that support communications technology. They can be adapted, in real time, to support any new communications invention and still permit backward-compatible operation with older technologies. For example, branding computer accounts by digital identification numbers designed to authorize playing of music branded to these identification numbers, may provide a new means of protecting intellectual property. Adaptive communications technologies, such as DRM, ultimately permit different types of command configurations with legal implications to be either mandatory or voluntary. ${ }^{67}$

Overall, the conversion from sequential and analog communications systems, such as railroads and telephony systems, to adaptive

63. See Ken Krechmer \& Elaine Baskin, Microsoft Anti-Trust Litigation-The Case for Standards, at http://www.csrstds.com/WSD2000.html (last updated Oct. 19, 2000). For further background, see generally sources cited supra note 12.

64. See E. Baskin et al., The Six Dimensions of Standards: Contribution Towards a Theory of Standardization, in Management of Technology, Sustainable Development and EcoEFFICIENCY 53 (Louis A. Lefebvre et al. eds., 1998) (alternatively referring to adaptive standards as 'Etiquette standards'); Krechmer, supra note 40, at 70.

65. Teehnically, these standards are said to negotiate the channel coding and source eoding. See Krechmer, supra note 40, at 70; see also Radin, supra note 10, at 1138-39 (describing elements of adaptive data exchange, including machine-made contracts, the development of Digital Rights Management Systems (DRMSs), and the development of extensible markup language (XML)).

66. See Baskin et al., supra note 64 , at 70.

67. See, e.g., Lex Informatica, supra note 3, at 572 (referring to test standards as inalienable commands and customization commands, respectively); see also discussion infra Part I.B. 
communications systems, such as the Internet, resulted in a paradigmatic shift in the definition of standards that regulate network environments. Specifically, there has been a shift away from the mere regulation of form, as designers of technological standards can now control proprietary enhancement of the standards' content, thereby controlling user behavior. Because of this change, technological standards should be analyzed in light of the epistemological distinction between rules and standards, and subject to retrospective evaluation through an optimal lawmaking analysis.

II

\section{Rules v. Standards: The Anomalous Dichotomy}

The operation of substantive legal commands in the physical world typically involves three consecutive stages. First, regulators decide whether conduct will be governed by a rule or a standard. These determinations are not always clear, as standards and rules differ in degree of generality, with standards being more general than rules. Rules and standards, in fact, are at opposite ends on the continuum of legal generality: Rules are specific, applying detailed legal consequences to a definite set of detailed facts, and creating a sharp line between forbidden and permissible conduct; standards are general and open-ended, specifying only a general limit of permissible conduct and requiring application of the standard to the particular facts of the case. ${ }^{68}$ Thus, the choice between rules and standards is also one of degree. ${ }^{69}$ Moreover, in cases where rules and standards play the same role, they may differ not even in matter of degree but merely in the formal means of their classification. ${ }^{70}$ Nevertheless, following the prevailing theory, I will treat the distinction in its polarized sense.

68. See Kaplow, supra note 21, at 560, 561-62 n.6 (referring to Ruth Gavison, Comment: Legal Theory and the Role of Rules, 14 Harv. J.L. \& PuB. POL'Y 727, 750-52 (1991)) (modeling degree of precision and time of application); see also Ehrlich \& Posner, supra note 4, at 258 (modeling degree of precision); Kennedy, supra note 21, at 1687 (studying thc influence of the degree of generality); Roscoe Pound, Hierarchy of Sources and Forms in Different Systems of Law, 7 TuL. L. REv. 475, $482-$ 83, 485-86 (1933); Frederick Schauer, Rules and the Rule of Law, 14 HARV. J.L. \& PUB. POL'Y 645, 650-51 (1991).

This distinction is not accepted by all. Dworkin, for instance, calls both rules and standards "principles"; other times, the term "standard" is described as a broad type of rules, standards, principles, and policies. Ronald Dworkin, Taking Rights SErIously 22-28, 72-80 (1977). Then, both are used as synonyms. See Frederick Schauer, Playing by the Rules: A Philosophical Examination of Rule-Based Decisionmaking in Law and IN Life 12-15 (1991) [hereinafter Playing BY THE Rules]; Thomas C. Arthur, Workable Antitrust Law: The Statutory Approach to Antitrust, 62 TUl. L. REv. 1163, 1225-28 (1988) (advocating a middle position in which the legislature identifies goals and offers examples as guides for courts); Margaret Jane Radin, Reconsidering the Rule of Law, 69 B.U. L. REv. 781, 783-90, 795-96 \& n.44 (1989); Pierre Schlag, Rules and Standards, 33 UCLA L. REv. 379, 406 (1985) (suggesting that any comparison might be a tautology or result in demonstrably untenable views).

69. See, e.g., Kaplow, supra note 21 , at 600 ; Kathleen M. Sullivan, The Justices of Rules and Standards, 106 HARV. L. Rev. 22, 57-58 n.231, 61 (1992).

70. See, e.g., Dworkin, supra note 23 , at 28. 
In the second stage, individuals make behavioral choices either to comply with the legal commands or not. Since most individuals are imperfectly informed, they first decide whether to acquire legal advice about the application of the legal commands to their situation. In the final stage, the legal command is enforced.

In all three stages, law and economics theory of optimal lawmaking is at odds with the present definition of "standards" or "technical standards" in network environments. This discrepancy arises from three sources: (1) the equilibrium between the sunk, fixed costs of command promulgation and variable costs (per case) of command enforcement of technological standards, (2) the degree of legal precision, and (3) the optimal timing of the lawmaking cost evaluation.

\section{A. Legal Standard Setting Cost Structure: The Anachronistic Equilibrium for Technological Standards}

\section{Introduction}

Louis Kaplow's optimal lawmaking model views the dichotomy between substantive rules and standards as a product of a tension between two types of costs: early fixed costs associated with promulgation of legal commands and the variable costs of enforcing them ex post. ${ }^{71}$ Standards that regulate substance tend to have lower initial promulgation costs and higher enforcement costs than rules. As Kaplow suggests, rules are typically more costly to promulgate than standards because rules involve ex ante determinations of the law's content. In eontrast, standards seem to be more costly for enforcement authorities to apply or legal advisors to predict due to the ex post requirement of determining their content. ${ }^{72}$ For example, in the physical world, a rule would specify an advance determination of the specific permissible driving speeds on specific urban roads, while a standard would leave both specification of what speed is permissible and other factual issues for the adjudicator. Thus, a standard might prohibit reckless driving at an excessive speed on urban roads. ${ }^{73}$ Ultimately, when standards are optimally utilized ex post, the value of alternative rules would typically be smaller and any promulgation of rules in such cases would be inefficient. However, when technological standards are treated as technical standards, no efficiency differential exists.

71. Kaplow, supra note 21, at 559. For an earlier analysis, see Louis Kaplow, A Model of the Optimal Complexity of Legal Rules, 11 J.L. ECON. \& ORG. 150 (1995). For examples of rules as ex ante regulation, see Colin S. Diver, The Optimal Precision of Administrative Rules, 93 YALE L.J. 65 (1983).

72. Kaplow, supra note 21 , at 562-63.

73. Id. at $559-60$. 


\section{Fixed Costs of Promulgation}

Traditional law and economics theory assumes that standards are cheaper to produce and keep up-to-date than rules. ${ }^{74}$ The rationale for this assumption is that standards are not given content in an authoritative manner until they are applied to particular behavior. ${ }^{75}$ Thus, promulgation costs of rules include both high sunk costs and uncertainty costs. Lawmaking promulgation costs are largely sunk and cannot be recovered if the enacted commands prove to be ineffective or undesirable at a later time. Promulgation incurs high sunk costs of three types. The first is the cost of legal intervention, including the direct legislative and political costs, publication costs, and notice costs of the results of regulation. Second, there are costs associated with promulgating a new rule or standard. These include the costs of disseminating information ${ }^{76}$ and acquiring information about the new law. ${ }^{77}$ Lastly, there may be adjustment costs if it becomes necessary to amend the command to adapt to changes from innovative activity. ${ }^{78} \mathrm{By}$ and large, these costs are irreversible, even if the legal command is not disseminated or is otherwise repealed.

In addition to sunk costs, promulgation may also incur uncertainty costs from high investment risks, which may result from a trial-and-error process of manufacturing new legal commands. ${ }^{79}$ Changes in social or economic circumstances may render a newly promulgated command obsolete over time, or the command may prove ineffective, thereby requiring revision. Both sunk and uncertainty costs can be divided into one-shot production costs and the sequential repetitive cost of revision.

\section{a.}

\section{One Shot Production Costs}

The first among the two categories of fixed costs of promulgation are one-shot production costs. They include high sunk costs for the standards' designers, uncertainty costs arising from the uncertainty, and high investment risks associated with protracted trial and error processes in the

74. Id. at 616 \& n. 168 (citing RichaRd A. Posner, Economic Analysis of LAW $\S 20.3$, at 543 (4th ed. 1992)).

75. The main point is that there is no universal tendency for standards as they are actually applied to be more complex than rules that would plausibly be promulgated. See Kaplow, supra note 21, at 596 . The complexity of legal rules refers to the number and difficulty of distinctions the rules make. See id. However, the more complex the rules, the morc costly it is for individuals to gain an understanding of the rules ex ante and for a court to apply them ex post.

76. See id. at 557-629.

77. See Erlich \& Posner, supra note 4 , at 267-86.

78. Id.

79. See BREYER, supra note 33, at 103, 109, 112; Eric J. lversen, Standardization and Intellectual Property Rights: Conflicts Between Innovation and Diffusion in New Telecommunications Systems, in Information Technology Standards and Standardization: A Global Perspective 80, 85-86 (Kai Jakobs ed., 2000). On inefficiency associated with protracted trial and error processes in manufacturing, see, for example, Paul A. David \& Shane Greenstein, The Economics of Compatibility Standards: An Introduction to Recent Research, 1 ECON. 1NNOVATION \& NEW TECH. 3 (1990). 
manufacturing of standards. There is also a time-cost tradeoff associated with the increased speed of innovation that diminishes the value of the regulatory process.

\section{i. Sunk Costs}

As technology advances, designers of prospective technological standards incur high sunk costs in obtaining accurate information. ${ }^{80}$ Like rules, technological standards incur high promulgation costs because they are detailed and specific. Like rulemaking, promulgation of technological standards generates substantial risk because of the standards' specific nature. This risk is evident, for example, in file sharing software with the ability to uphold copyrights in MP3 digital works of art. This software acts as a complex rule whose violation leads to enforcement measures such as loss of access or destruction of the infringing file. As technological standards develop, copyright owners in network environments may gain not only the ability to control the duplication of copyrighted materials, but also the ability to control the actual use of copyrighted materials. They could control how often a text could be accessed or read, whether the user could cut parts of the text and paste them into other texts, and whether and how many times the text could be printed. Ultimately, copyright owners could control whether such works of art could be digitally shared. ${ }^{81}$ These possibilities increase the risk of error by the standard's designers. These types of specifications are close-ended by design and technically irreversible. As such, there is a significant risk of error in manufacturing, potentially resulting in a high level of path-dependency or the adoption of a wrong standard.

Technological standards can channel behavior by upholding alternative social values and legal entitlements than the one embedded in them by their designers. ${ }^{82}$ Copyright protcction provided by technological standards

80. See generally Michael B. Spring \& Martin B. H. Weiss, Financing the Standards Development Process, in Standards Policy For Information Infrastructure 289, (Brian Kahin \& Janet Abbate eds., 1995) (suggesting that the main development costs arise from the time, travel, and salaries of the committee members); $c$. BREYER, supra note 33, at 103, 109, 112 (describing information collection as the main set of costs in standard setting at large); Tim Sloane et al., Efficient Business-to-Business Relationships: How Analytics and XML Can Help, Web Techniques, Nov. 2000, available at http:/www.webtechniques.com/archives/2000/11/sloane/ (last visited Mar. 25, 2004) (emphasizing that the biggest threat to the future of collaborative commerce is that collaborative commerce will be stalled by companies' inability to share information with trading partners).

81. See, e.g., Mark Stefik, Shifting the Possible: How Trusted Systems and Digital Property Rights Challenge Us to Rethink Digital Publishing, 12 BeRKELEy TECH. L.J. 137 (1997); Jonathan Weinberg, Hardware-Based ID, Rights Management, and Trusted Systems, 52 STAN. L. REv. 1251 (2000); Mark Stefik, Trusted Systems, Sci. AM., Mar. 1997, at 78.

82. See Burk \& Cohen, supra note 14, at 53-54; see also Julie E. Cohen, A Right to Read Anonymously: A Closer Look at "Copyright Management" in Cyberspace, 28 ConN. L. REv. 981 (1996); Julie E. Cohen, Lochner in Cyberspace: The New Economic Orthodoxy of "Rights Management," 97 Mich. L. Rev. 462 (1998); Julie E. Cohen, Some Reflections on Copyright Management Systems and Laws Designed to Protect Them, 12 BeRKeley TeCH. L.J. 161 (1997); Weinberg, supra note 81 . 
could be flexible if the standards were created to reflect the legal exceptions to copyright protection. In the DRM setting, for example, copyright holders could build into rights management systems some level of discretionary access for fair use. ${ }^{83}$ The goal of integrating an adequate level of discretionary access for users can be achieved, at least in theory, by "performance standards," defined in section 3(c) of the National Technology Transfer and Advancement Act (NTTAA) of 1995. Performance standards set a technical goal that could be met by more than one method of achieving the desired end. This set of possibilities intensifies the risk of error by its designers. In theory, performance standards could be used instead of prescriptive standards, which specify finite design requirements, including the materials to be used, how a requirement is to be achieved, or how an item is to be constructed. Furthermore, many economic studies have shown that performance standards are superior to prescriptive standards in encouraging innovation. ${ }^{84}$

Past attempts have been made to set performance-based technological standards. For example, the aborted Conference on Fair Use (CONFU) sought to create fair-use technological standards for digital works. ${ }^{85} \mathrm{At}$ least for now, however, designing DRM standards that approximate both the results of individual judicial determinations and the overall dynamism of fair use jurisprudence is still largely impractical. ${ }^{86}$ Consequently, programmed fair use functionality in DRM standards is static, narrow, and best designed as prescriptive standards.

The strictness of these technological standards contrasts with the dynamic nature of legal standards, and, in this respect, technological standards are similar to legal rules. Moreover, with the commercialization of the Internet and the ensuing growth in the number and influence of de facto standard setters, the performance-based type of technological standard is being increasingly replaced by the prescriptive type. ${ }^{87}$

Unlike rules and technological standards, legal standards, such as the fair use doctrine in copyright law and calculations of compensation for damages, leave their application and definition to be determined at the time

83. See Burk \& Cohen, supra note 14 , at 56 .

84. For studies and references, see Anton \& Yao, supra note 10, at 248-49 (describing an approach of assessing whether standards are reasonably necessary), and Sean P. Gates, Standards, Innovation, and Antitrust: Integrating Innovation Concerns into the Analysis of Collaborative Standard Setting, 47 EMORY L.J. 583, 651 (1998).

85. See Burk \& Cohen, supra note 14, at $56 \mathrm{n} .45$ (citing INFORMation INFRASTRUCTURE TASK Force, Intellectual Property and the National Information Infrastructure: The Report of the Working Group on 1NTEllectual Property Rights 83-84 (1995)) (discussing establishment and progress of CONFU).

86. Id. at 56.

87. See, e.g., Kevin Werbach, Fed. Communications Comm'n, Digital Tornado: The Internet AND Telecommunications Policy 17 (1997) (Working Paper), available at http://www.fcc.gov/Bureaus/OPP/working_papers/oppwp29.pdf (last visited Mar. 25, 2004); Larry Seltzer, The Standards Industry, INTERNET WORLD, Apr. 15, 2001, at 50. 
of enforcement. Technological standards, like legal rules, are less flexible than legal standards and incur less interpretation during enforcement. This increases the irreversible expenditures of promulgation and the risk of error in the design of these commands.

\section{ii. Uncertainty Costs}

In addition to the sunk costs of promulgating legal commands, a cost arises from the uncertainty and high investment risks associated with protracted trial and error processes in the manufacturing of standards. ${ }^{88}$ Because legal rules have higher promulgation costs than standards, the expected value of investment in rules declines relative to standards in conditions of high uncertainty. Therefore, increased uncertainty should result in increased use of standards. In recognition of this, authorities responsible for standardization in cyberspace encouraged cooperation and open access to design processes to reduce uncertainty in the manufacturing process. ${ }^{89}$ These policies were designed to prevent research and development from overlapping and increase the expected value of investment in technological standards. ${ }^{90}$ With this goal in mind, Congress passed the National Cooperative Research Act (NCRA) in 1984 and the National Cooperative Research and Production Act (NCRPA) in 1993..$^{91}$ Both acts were aimed, indirectly, at facilitating and cheapening decentralized commercial standardization initiatives. Uncertainty costs have bccn further reduced by expanding the voluntary promotion of electronic publishing of research materials.

88. See sources cited supra note 79.

89. The principles, which ensure open access to intellectual property rights, requiring nondiscriminatory access on a fair and reasonable basis, were adopted by many standardization industry organizations, such as American National Standard Institute (ANSI), ISO, International Electotechnical Commission (IEC), ITU, and the Internet Engineering Task Force (IETF). See the standards proposals and main standards of the IETF industry standardization organization, at http://www.ietf.org. See also Petri Mähönen, infra note 95, at 44 (citing Henry J. F. Ryan, ISO/IEC JTC l Directions in Multimedia and GII standards, IEEE COMM. MAG., Sept. 1998, at 108).

89. LEE, supra note 48 , at $128-29$ (using the example of the wireless phone industry and suggesting that their joint interoperable failure has been neither on consensual nor on technical grounds, but because of the ability, given CCI rules, of core groups to dominate the standard-setting process).

90. See, e.g., CARGill, supra note 3, at I31-38; Thomas M. Jorde \& David J. Teece, Acceptable Cooperation Among Competitors in the Face of Growing International Competition, 58 ANTITRUST L.J. 529, 538 n.28 (I989); Memorandum from A. Lyman Chapin, Chair, Internet Activities Board, on the Internet Standards Process (March 1992), available at http://ffc.sunsite.dk/rfc/rfcI3l0.html (last visited Mar. 25, 2004).

91. National Cooperative Research and Production Act of 1993, 15 U.S.C. $\S \S 430$ I-06 (2000); see also H.R. 1604, I02d Cong. (1991) (bill to amend the National Cooperative Research Act of 1984); Jack E. Brown, Technology Joint Ventures to Set Standards or Define Interfaces, 61 ANTITRUST L.J. 92I, 933 \& n.5 (I993) (suggesting that the congressional concern in promoting joint activities was also reflected in the repeated legislative attempts to broaden the NCRA's protections to joint production and manufacturing, as well as research ventures). 
Designers of prospective technological standards incur substantial information costs. In addition, the cost structure of designing technological standards involves high uncertainty investment risks in the form of research and development costs. Both types of costs suggest, in fact, that the early promulgation of technological standards, like with legal rules, would mirror the promulgation of optimal legal rules, and thus would save those parties the time, cost, and error inherent in coordinating an inefficient rule, subject to reimbursing low transaction costs.

\section{iii. The Time-Cost Tradeoff}

The speed of production of technological standards has increased in comparison to technical standards. Particularly, the increased speed of innovation raises the sunk costs and risks of their standardization. ${ }^{92}$ Furthermore, this increased speed diminishes the value of the regulatory process since regulation is pursued less in anticipation of innovative activity. This contrasts with the development of technical standards in the early development phase of the Internet and the industrial age.

Traditionally, industrial age innovation followed a linear progression from scientific discovery to applied research and development, followed by production and marketing. In the information age, however, the speed of technological growth has increased in proportion to the time necessary to create technological standards. Consequently, the time required to develop technological standards has become longer than the product life cycle. ${ }^{93}$ Thus, while in the industrial age one first created a product and then standardized it, in the information age standards are needed before products, and compatibility with existing standards is a preliminary condition to enter the market. ${ }^{94}$

In the early development of cyberspace, bodies responsible for creating standards began to cope with this production constraint by anticipating technology and developing standards before products were produced.$^{95}$ The resulting standards were known as anticipatory standards and included the standardized V.32 modem, integrated services digital network (ISDN), and TCP/IP. ${ }^{96}$ With the increase in the speed of innovative activity, this approach created difficulties, however. Anticipatory standards did not take

92. See Frederic M. Scherer, Time-Cost Tradeoffs in Uncertain Empirical Research Projects, in InNovation ANd Growth: Schumpteterian Perspectives 67-82 (1984).

93. See, e.g., International Organization for Standardization, A Vision for the Future: Standards Needs for Emerging Technologies (1990).

94. Id.

95. CARgIll, supra note 3, at 45-46; Petri Mähönen, The Standardization Process in IT - Too Slow or Too Fast?, in INFORMATION TECHNOLOgY STANDARDS AND STANDARdization: A Global Perspective, supra note 79, at 35, 38 (emphasizing that "the place for innovations is outside the formal standards meeting - standards just agree on the solutions").

96. See Michael J. Bonino \& Michael B. Spring, Standards as Change Agents in the Information Technology Market, 12 COMPUTER STANDARDS \& INTERFACES 97, 99 (1991). 
into account fast-moving research and development work and innovations, even at the technical committee level. Instead, new innovations had to comply with the standards, causing state-of-the-art technology to "freeze" to the standards and thus reducing its ability to be dynamic. In other words, while anticipatory standards were typically designed to respond to existing technology specifications, they did not take into account the speed of the new innovations. The need to respond to new technology while still providing meaningful standards, combined with the growth in consumer demand for standardized products, requires an increase in the speed with which standards are promulgated to decrease the risk of error in manufacturing standards.

The cost of promulgating technological standards is also increased by the growth in the number of standard setting participants that have diverging preferences. Specifically, the embedded costs of coordinating a large number of standards setters with different preferences increases the cost of standard production. ${ }^{97}$ All other things being equal, the legal command that ought to be initially promulgated is the one that is supported and adopted by the most parties, where transaction costs are low enough for negotiators to tailor the commands to their own preferences. However, when these one-shot coordination costs are high, early promulgation of legal rules is inefficient. In these cases it would be more efficient to use general legal standards instead of specific rules.

Due to the fast-moving nature of adaptive and compatible technological standards, anticipatory technological standardization is now practically "dead." It has been replaced by two kinds of standardization production processes: "participatory" standardization and "responsive" standardization. Participatory standards are developed, tested, and used in an interactive environment. ${ }^{99}$ Users are treated as codevelopers, thus increasing the speed of software improvement and debugging. Standard developers try to use as large a beta tester and codeveloper base as possible, increasing the speed with which problems are identified and fixed. ${ }^{100}$ This type of

97. In fact, in the early development phase of the Internet, anticipatory standards acted as mechanisms for collective planning and were the embodiment of a central institutional policy. See id.

98. In a conversation between the author and Carl Cargill, Director of Corporatc Standards, Sun Microsystems, Inc., Mr. Cargill suggested that anticipatory standard-setting activity (as took place in the early phase of cyberspace standardization) is now practically "dead" as a result of the move to standardize "existing practice." Interview with Carl Cargill, Director of Corporate Standards, Sun Microsystems, Inc., at Sun Microsystems headquarters in Menlo Park, Cal. (Mar. 2003).

99. Internet applications above the TCP layer may be considered participatory standards, such as MBONE and the MMUSIC standards. See Baskin et al., supra note 64, at 63; cf. T. M. Egyedi, Institutional Dilemma in ICT Standardization: Coordinating the Diffusion of Technology?, in Information Technology Standards and Standardization: A Global Perspective, supra note 79 , at $48,54-55$ (suggesting that, in fact, application standards development has begun to occur in tandem with the innovative process of technological standards' subject-matter).

100. See Baskin et al., supra note 64 , at 62 . 
standardization is unique to cyberspace. ${ }^{101}$ Responsive standards are designed in reaction to products or services that have been sold and widely adopted, ${ }^{102}$ such as the UNIX operating system and programming languages. ${ }^{103}$

In sum, the decentralization of commercialized standard setting has eroded anticipatory standardization, which acted as a mechanism for collective planning and embodied the establishment of a central regulatory policy. Market and industry technological standardization is now initiated and driven by commercial implementers. ${ }^{104}$ Thus, there has been a shift from anticipatory standardization where the standard supported by the largest number of parties was agreed upon and adopted, to a growth in the number of participants with different, often incompatible, preferences. The increase in the number of participants, on the one hand, and the increase in spread of standardizing innovations, on the other, has ultimately increased the sunk costs of promulgation. ${ }^{105}$

\section{b. Repetitive Revision Costs}

Optimal lawmaking theory assumes that because legal rules are more rigid than legal standards, they will need to be updated more frequently. ${ }^{106}$ The more detailed a rule is, the more often it will have to be changed. Updating legal commands generates costs, and because rules are changed more frequently than standards, updating costs are higher for rules. As with the initial promulgation of the command, these costs include the costs of producing the new command plus additional costs arising from the uncertainty of changing the law. ${ }^{107}$

Rules must be updated more frequently than standards because the circumstances underlying rules will change over time. Rules specify the circumstances relevant to a decision and the weight that should be given to each circumstance. If any individual circumstance changes, the rule may

\section{Id.}

102. Id. This technique is not unique to cyberspace. On early experience with responsive standardization in telecommunication markets, see M. H. Sherif, Contribution Towards a Theory of Standardization in Telecommunications (1999), at http://www-i4.informatik.nwth-aachen.de/ jakobs/ siit99/proceedings/Sherif.doc (last visited Mar. 25, 2004).

103. Notably, among the programming languages with the widest installed base are Digital Property Rights Language (DPRL) and eXtensible rights Markup Language (XrML) 2.0. See GiantSteps Media Technology Strategies, eXtensible Rights Markup Language (XrML), Version 2.0 (Nov. 28, 2001), available at http://www.giantstepsmts.com/DRM\%20Watch/xrml20.htm (last visited Mar. 25, 2004).

104. See, e.g., Baskin et al., supra note 64. Due to high market demand followed by the decrease in anticipatory standardization, large users with specific needs may force standards creators to become standards seekers. $l d$.

105. Id. at 54-55 (suggesting that, in fact, application standards development has begun to occur in tandem with consumer demand).

106. See Ehrlich \& Posner, supra note 4, at 278; Kaplow, supra note 21, at 596.

107. See Ehrlich \& Posner, supra note 4, at 278; Kaplow, supra note 21, at 596. 
become ineffective. To illustrate, lawmakers may assign a speed limit of thirty-five miles per hour to a stretch of road with the goal of promoting safe but efficient driving based on the circumstance that the road has multiple curves. If the road is straightcned, the speed limit becomes inefficiently low and no longer achieves the lawmakers' goals. ${ }^{108}$

Standards, on the other hand, are relatively unaffectcd by changes to the circumstances in which they are applied. This is because, as explained, standards only generally indicate the circumstances in which they apply. Standards do not specify the circumstances relevant to their application or the weight to be given each circumstance. ${ }^{109}$ Again, to illustrate, regulators may create a standard requiring driving at "reasonable speed" for all roads in the area. Standards are given definite meaning only when applied to particular conduct. Therefore, a change in the road might change what an adjudicator views as a "reasonable speed," but the change does not affect the standard's ability to promote the goals of safe and efficient driving. Thus, a standard can be applied decades after it was promulgated using a present understanding of the standard's meaning rather than relying on revisions to the standard's text.

In this respect technological standards are more like rules than standards. They specify the use of specific technologies to achieve their goals; if the technology changes, the goal may no longer be achieved. Therefore, technological standards must be frequently revised and updated. In fact, the frequency and quality of revision is not merely a supplementary consideration for its designers, but rather an independent type of cost constraint that inherently defines the technological standard's level of compatibility with varying, ever-changing technologies. Because the life cycle of standardized network technology is short, ${ }^{110}$ the traditional process of revising is too slow. Furthermore, the need for frequent revision of technological standards creates additional revision costs by curtailing the optimal period of debate about the content of the standard. This limits the standard designers' ability to forecast the standard's technological and economical success and reduces the quality of the standard. ${ }^{11}$

108. See Ehrlich \& Posner, supra note 4, at 278; Kaplow, supra note 21, at 596.

109. Ehrlich \& Posner, supra note 4, at 277.

110. Technological standards in cyberspace have increasingly shortened product life cycles, which then result in the costly design of product generations. This is the casc, for example, with Microsoft's Internet Explorer browsers. Microsoft plans to release a plug-in to Internet Explorer that will embed DRM functionality into the Web browser and then release versions of Microsoft Offiee applications with the functionality built in. See Ross Anderson, "Trusted Computing" Frequently Asked Questions (Aug. 2003), at http://www.cl.cam.ac.uk/ rjal 4/tcpa-faq.html (last visited Mar. 25, 2004).

111. See, e.g., CARGILL, supra note 3, at 170-74; WERBACH, supra note 87, at 5 ("Likc a digital tornado, the vortex continues, as the new level of demand creates the nced for additional capacity, and so forth."); see also Paul Lowe, The Management of Technology: Perception and OPPORTUNITIES 294 (1995). 


\section{Variable Costs (Per Case) of Enforcement \\ a. General}

Standards and rules also differ in their costs of enforcement. ${ }^{112}$ Because standards are general and normatively vague, they are more costly to enforce than rules. The application of standards requires substantial interpretation, and the uncertain outcome of the interpretation may increase attempts to avoid compliance at the margins. The increased precision of legal rules, on the other hand, leads to fewer requests for interpretation ${ }^{113}$ and results in quick and accurate enforcement of the disputes that do arise. ${ }^{1 / 4}$ The relative ease and greater certainty of enforcing rules also discourages would-be violators from making socially wasteful efforts to avoid compliance, thus further decreasing enforcement costs. ${ }^{115}$

In network environments, technology's role in enforcing property rights has evolved from facilitating legal enforcement to largely replacing the need for such enforcement. As a result of this fundamental change, relatively few legal enforcement measures are taken to support operational technological self-enforcement. In the physical world, on the other hand, enforcement of proprietary rights over information has remained essentially legal in nature and is still pursued primarily through registration forms, license agreements, and copyright laws. This was also the case in network environments prior to the introduction of DRM technology. Technical standards still largely required legal enforcement and merely provided enforcers with an audit trail, such as copyright notices or watermarked identifiers embedded permanently in the content. ${ }^{116}$

With the emergence of technological standards, enforcement has finally been integrated into technology, as the new standards utilize encryption and user authentication to restrict access to content in strictly specified conditions. ${ }^{17}$ Technological devices can now be readily developed to monitor and guarantee compliance with both general legal norms and specific policy rules. Thus, technological standards may be designed to prevent unauthorized actions. The precision with which technological standards can control behavior essentially provides built-in and automated self-enforcement, thus substantially reducing legal and other enforcement costs. Technological standards also marginalize the costs of monitoring,

112. Gavison takes this argument further, suggesting that only the strength of entrenchment and not the breadth of recognition should be incorporated in the concept of a rule. Ruth Gavison, Comment: Legal Theory and the Role of Rules, 14 HARv. J.L. \& PuB. PoL'Y 727, 750-52 (1991); see also Colin S. Diver, supra note 71 , at 69 (referring to a legal rule that states, "No person may pilot a commercial airplane after his sixtieth birthday").

113. Diver, supra note 71 , at 69.

114. Id.

115. Ehrlich \& Posner, supra note 4, at 262.

116. See GiantSteps Media Technology Strategies, supra note 55.

117. Id. 
identifying, and executing enforcement, and do not require interpretation during enforcement.

The capability and use of technological standards substantially mirrors the cost structure of legal rule enforcement. By preventing noncompliance, technological standards have drastically reduced enforcement costs. The next section will assess this cost structure constraint measured through its uncertainty and irreversible costs.

\section{b. Uncertainty Costs}

The precise nature of rules reduces the cost of learning the rule and determining how the rule would apply to the intended conduct. ${ }^{18}$ In comparison, standards require costly interpretation efforts because the meaning of the standard is developed over time in individual enforcement cases. ${ }^{119}$ According to a seminal article by Colin Diver, there are two reasons why precision may increase compliance and decrease evasion or concealment. ${ }^{120}$ Notably, both of these reasons apply to the use of technological standards as well as legal rules. First, the precise nature and degree of compliance with lcgal rules and technological standards depends on the risk aversion of the individual. Second, whether the ideal time to acquire and disseminate information about legal commands is before or after promulgation depends, most importantly, on the frequency of individual application and on adjudication. ${ }^{121}$

\section{i. $\quad$ Risk Aversion Preferences}

Risk aversion is relevant to the analysis of rules and standards for two reasons. First, the behavior of individuals typically correlates to their individual risk preferences. ${ }^{122}$ Second, when individuals are risk averse, their bearing of risk is socially undesirable. ${ }^{123}$ Thus, applying legal commands generates costs for both the legal system, including the cost of judges who must determine whether the defendants have complied, and for private actors who have to determine the level of precaution necessary to escape liability. If, however, the cost of predicting becomes too high, individuals will not choose to become as well informed about how regulation would apply to their behavior. As a result, it may be more valuable for the cost of legal advice to be low, thus favoring rules over legal standards. ${ }^{124}$ If the

\footnotetext{
118. Diver, supra note 71 , at 73 .

119. Id. at 72

120. Diver, supra note 71 , at 73.

121. Kaplow, supra note 21 , at 563.

122. Id. at 605 .

123. Id.

124. Id.; Ehrlich \& Posner, supra note 4, at 270.
} 
benefits of learning the law's content are significant and the costs of legal advice are low, individuals' conformity to legal commands increases. ${ }^{125}$

On the other hand, if the costs of determining what constitutes conformity with legal standards are high, individuals will not choose to become as well informed about how standards would apply to their behavior. This will cause noncompliance to increase, thus also increasing the cost of enforcement. ${ }^{126}$ Because rules have a lower information cost than standards, use of rules increases compliance and induces behavior that is more in accordance with the rule's underlying norms. ${ }^{127} \mathrm{~A}$ high degree of legal certainty also reduces the number of legal disputes since parties are more likely to settle the case themselves in the shadow of the law. ${ }^{128}$ Overall, because individuals tend to be less informed concerning standards, they may bear more risk under standards. In extreme cases this advocates for the use of rules. ${ }^{129}$

Like rules, technological standards are less expensive to enforce than legal standards and have lower learning costs resulting from uncertainty, since it is relatively easy to determine what conduct the technological standard covers. The comparative ease of determining the scope of technological standards is due to both the specificity of the standard and the use of certification mechanisms to indicate when a product is utilizing a technological standard. ${ }^{130}$ ln cyberspace, industry standardization organizations, such as the Internet Engineering Task Force (IETF) ${ }^{131}$ and the World Wide Web Consortium (W3C), ${ }^{132}$ formally monitor standard setting. Standardization is largely achieved by creating a consumer consensus around individual technologies, similar to a social consensus around legal rules. Technological standards can be analogized to technically advanced products in markets where information concerning quality is more costly to supply and process than information regarding price. That is because performance is multidimensional and may require various value measurements

125. Ehrlich \& Posner, supra note 4, at 270; Kaplow, supra note 21, at 596.

126. Ehrlich \& Posner, supra note 4, at 270; Kaplow, supra note 21, at 565-66.

127. Ehrlich \& Posner, supra note 4, at 270; Kaplow, supra note 21, at 565-66.

128. See generally Hans-Bernd Schäfer, Precise Legal Norms as Substitutes for Human Capital in Low-Income Countries, Universität Hamburg-Institut für Recht und Ökonomik (Working paper 2003).

129. Kaplow, supra note $2 \mathrm{I}$, at 605.

130. On certification mechanisms, see George A. Akerlof, The Market for "Lemons": Quality Uncertainty and the Market Mechanism, 84 Q. J. ECON. 488 (1970), Michael J. Trebilcock, Regulating Service Quality in Professional Markets, in The Regulation of Quality 83 (Donald N. Dewees ed., I983), and Kip W. Viscusi, A Note on "Lemons" Markets with Quality Certification, 9 Bell J. EcoN. 277 (1978).

131. The IETF is the body that defines standard Internet operating protocols such as TCP/IP. Their standards are expressed in the form of Requests for Comments (RFCs). See, 1ETF's web site, available at http://www.ietf.org (last visited Mar. 26, 2004).

132. The $\mathrm{W} 3 \mathrm{C}$ is an industry consortium that seeks to promote standards for the evolution of the Web and interoperability among www products by producing specifications and reference software. See The W3C Web Site, at http://www.w3c.org (last visited Mar. 26, 2004). 
involving substantial computer processing and interaction with customersupplied information such as authentication, data storage, and retrieval. ${ }^{133}$

Industry standardization organizations act as public agents with sufficient information to make and certify quality judgments by attaching a widespread industry-based conscnsus around individual technologies. These organizations act as a monitoring proxy for averagely informed consumers approaching technological standard markets. In a manner similar to the creation of social awareness of legal rules, technological standards increase individuals' understanding of their content thereby increasing compliance with their commands. Specifically, certification mechanisms and efficient product advertising of technological standards are valuable in lowering the overall costs of ex ante legal advice. However, while they do decrease learning costs, certification mechanisms, for both physical and digital products, are unable to marginalize these costs to zero. Individuals must still expend learning costs to avoid any remaining uncertainty. The remaining costs of learning, including the cost of obtaining legal advice, largely correlate to the factor of risk aversion, as discussed above.

Technological standards do, nevertheless, have lower uncertainty costs than either standards or rules because they force compliance by the user. Conformity to technological standards is, in fact, embedded in the initial decision to use the technology. With little risk of noncompliance, there is no need to incur costs to avoid risk. In this way, technological standards circumvent the traditional law and economics explanation for the low enforcement cost of rules. Because of their specific nature, rules generate lower uncertainty costs, thereby increasing compliance and lowering enforcement costs. Technological standards, on the other hand, are designed to prevent noncompliance, and therefore reduce the need for enforcement, while providing the additional benefit of reducing the expenditure of resources required to learn how to achieve compliance.

\section{ii. Frequency of application}

Because legal rules have lower enforcement costs than standards, their advantage increases with the frequency with which they are applied. This is also true for the uncertainty cost component of enforcement costs. The increased noncompliance (and corresponding need for more enforcement) resulting from decreased uncertainty multiplies as the number of times the command will apply increases. Consequently, the choice between rules and standards depends on the frequency the rule or standard will be applied and adjudicated. ${ }^{134} \mathrm{~A}$ command that is applied with a low frequency or to a variety of circumstances is best written as a standard, as demonstrated by the

133. Antitrust, Innovation, and Competitiveness 9 (Thomas M. Jorde \& David J. Teece eds., 1992).

134. Kaplow, supra note 21 , at 563. 
standard of negligence which addresses a wide range of possible circumstances, many of which are materially different from each other. ${ }^{135}$ Because, the particular circumstances causing a given accident are unlikely to occur repeatedly, the use of a standard makes sense from an enforcement cost perspective. ${ }^{136}$ Alternatively, legal rules are increasingly desirable the greater the frequency of application, as demonstrated by regulations governing health and safety, many traffic rules, and aspects of damages (e.g., how to value disability, loss of life, and lost profits). ${ }^{137}$

Rules are preferable in cases of frequent application because promulgation costs are borne only once, while efforts to abide by and enforce them occur with every individual situation. ${ }^{138}$ Technological standards, like mass consumption products, are desigued to achieve economies of scale based on the assumption of a stable and profitable installed base. ${ }^{139}$ Like rules, technological standards are predesigned to be disseminated and applied in high frequency. Because technological standards have low enforcement costs, they are justifiable where they will be frequently used.

\section{c. Irreversible Costs}

Many legislative and judicial costs required to implement legal changes are sunk and cannot be recovered if an enacted command proves undesirable. Irreversible costs also result from the discontinued operation of an existing command, including the lost value in the specialization of attorneys and other agents and investments by law enforcement agencies. Furthermore, the discontinuation of existing legal commands results in a loss of alternative enforcement mechanisms such as widespread social norms, causing the enforcement of new commands to be less efficient.

Technological standards seem to have left little of this analysis intact. This is a result of their initial cost structure and the reduction of internal and external enforcement factors, namely internal technical design and external relations with the legal system. First, meaningful sunk costs of enforcement may not even exist in the case of technological standards, since technological standards diminish enforcement costs so substantially. ${ }^{140}$ Not

135. Heterogeneity of legal commands, in negligence cases, for example, is emphasized because application is said to be frequent only if the individual acts have enough in common to be treated similarly. See Werner Z. Hirsch, Reducing Law's Uncertainty and Complexity, 21 UCLA L. Rev. 1233, 1240-41 (1974).

136. Kaplow, supra note 21 , at 564 .

137. Id. at 563-564.

138. Id. at 577 .

139. Notably, in the DRM-enabled setting, Microsoft has stated that Palladium, Microsoft's future secure DRM-enabled computing architecture, would nced an installed base of 150 million units to make an impact on the market for DRM-enabled PCs. For evidence supporting these path dependency estimates for 2008, see, for example, Ross Anderson, TCPA/Palladium Frequently Asked Questions (Aug. 2003), available at http://www.cl.cam.ac.uk/ rjal 4/tcpa-faq.html (last visited Mar. 25, 2004).

140. See discussion infra Part 111.D. 
only have the costs of monitoring, identifying, and executing enforcement been marginalized, these costs are then assessed ex ante in the promulgation or development phase, reducing otherwise ex post sunk costs of enforcement.

Second, theory suggests that legal standards reduce the incidence of enforcement errors because their flexibility allows the adjudicator to consider variables that may not have been considered by their drafters. Rules, on the other hand, reduce the incidence of enforcement error from institutional incompetence or bias ${ }^{141}$ because they limit the number of relevant factors to be considered in their enforcement both internally and externally. ${ }^{142}$

Technological standards are internally constrained by their inability to be designed as general legal norms that approximate both individual judicial determinations and socially beneficial jurisprudence. ${ }^{143}$ For example, programmed fair use functionality in DRM standards is static by design and unable to consider unique circumstances that might call for varied applications. The automated enforcement of the standards reduces the number of relevant internal factors that can be considered. For the same reasons, when technological standards receive additional legal enforcement by courts (which are subject to high costs of tracking and obtaining jurisdiction over infringing parties), they will result in lower costs of error due to judicial incompetence or bias.

Enforcement of technological standards is also subject to an external constraint on its performance. Because there is no normative hierarchy of law based on technological standards, irreversible costs of enforcement are independent from the performance of the entire hierarchical system of laws. Any loss would be internal, specific to the design measurements of any given technological standards and not subject to supplementary external enforcement costs. As internal enforcement costs, such losses are limited to the costs resulting from the use of the technological standard, including costs resulting from various imperfections such as a lack of backward compatibility, malfunction, and bugged design. Such costs may also result from illegal hacking or other activities that circumvent the standard.

The dichotomy between legal rules and standards can be seen as a product of a tension between two types of costs: costs associated with fixed promulgation of legal commands and the variable costs (per case) of enforcing them. Overall, technological standards tend to have high initial promulgation costs relative to legal standards, but lower enforcement costs. In the promulgation stage technological standards carry sunk costs that

141. Playing By The Rules, supra note 68 , at 149-50.

142. Id.

143. Burk \& Cohen, supra note 14 , at 56. 
cannot be recovered if the enacted command proves to be ineffective or undesirable at a later time and uncertainty costs of high investment risks that result from the trial and error processes of promulgation. Enforcement considerations, on the other hand, suggest low costs associated with both the adaptation to preferences of risk averse users of such technology and the frequency of individual application and adjudication of the technological standards. The analysis of both promulgation and enforcement costs thus suggests additional conformity of technological standards to legal rules.

\section{Degree of Legal Precision}

As explained earlier, the correlation between the degree of precision and the type and number of legal commands is fundamental to the analysis of optimal rulemaking. Rules are often more complex than standards; while a particular rule might be very simple, such as a posted speed limit of fiftyfive miles per hour, the entire set of rules necessary to cover the same ground as a standard is likely to be more complex. ${ }^{144}$ Optimal rulemaking analysis suggests that the ability to be precise in formulating legal commands increases the number of rules. ${ }^{145}$ Any exogenous effect that increases the benefits or reduces the costs of legal precision would increase the optimal precision and number of rules. ${ }^{146}$ This Part examines three results flowing from the degree of precision: (1) the variable degree of overand under inclusiveness in the design of rules relative to standards, (2) their variable degree of nonintuitiveness, and (3) the constant parameter for their syllogistic deductive reasoning.

In predicting the degree of precision of standards and rules it is necessary to determine their over- and under inclusiveness of the behavioral preferences of individuals. Rules, by design, tend to be more over- and under inclusive than standards and thus tend to outlaw conduct that an optimal rule is intended to legitimize and to permit conduct that an optimal rule would outlaw. ${ }^{147}$ Although a rule is typically more costly to promulgate than a legal standard, there is no way to determine whether a rule or standard is over- or under inclusive until enforcement. At the promulgation stage, therefore, there is little difference between rules and standards in

144. Richard A. Posner, Economic Analysis of LAw 592 (5th ed. 1998).

145. Ehrlich \& Posner, supra note 4, at 272; see also id. at 258 (modeling degree of precision); Kaplow, supra note 21, at 560, 561-62 n.6 (modeling degree of precision and time of applieation); Kennedy, supra note 21, at 1687 (modeling degree of generality).

146. Ehrlich \& Posner, supra note 4, at 272. Conceptually, Ehrlich and Posner's main eoncern is with precision of law even before any ehoice between rules and standards is made. Id. at 259 .

147. See id. at 268-70; Kennedy, supra note 21 , at 1689, 1695. But see Kaplow, supra note 21 , at 595-96. Based on existing practiee and for matters of generality, this analysis implicitly assumes a comparison between a simple standard and a relatively complex rule. In a few eases, however, both rules and standards can in fact be quite simple or highly detailed in their operation. See, e.g., Diver, supra note 71 , at 72 . 
terms of their over- or under inclusiveness. In the enforcement phase, however, standards decrease errors of over- and under inclusiveness by giving the decision maker more discretion. ${ }^{148}$ In contrast, a rule captures the background principle or policy incompletely and therefore produces more errors of over- or under inclusiveness. ${ }^{149}$ In either case, the behavior of individuals will be the same, other things being equal. However, at the enforcement stage, applying the standard will be more costly.

Following this analysis, it is also clear that turning a strictly defined rule into a widely applicable standard may be wrongly perceived to permit unintended conduct. This problem can be avoided by making deliberately overinclusive rules. In other words, the less exact and detailed a rule, the more likely it is to open up loopholes and to permit by implication conduct that an optimal rule is intended to forbid. In the design of technological standards this observation is of crucial importance, as it increases the danger of mistaking rules with inefficient loopholes for efficient standards. This loophole effect can be minimized by creating a consciously over inclusive rule. For instance, a regulator might establish a speed limit that is lower than the optimal speed.

Technological standards, like rules, run high risks of over- and under inclusiveness. To avoid these problems, technological standard setters would have to build the entire range of possible uses and outcomes into the programmed standard. This would require both a perplexing complexity and an impractical amount of prescience. To date, there are no algorithms capable of producing such an analysis, and no such algorithm is being used. ${ }^{150}$ In response to this problem, technological standard setters have chosen to create standards that are often problematically overinclusive by design. ${ }^{151}$ One example of this is Microsoft's DRM-oriented operating system. In June 2002, Microsoft released information regarding its new digital rights management operating system (DRMOS), known as "Palladium."152 Palladium is a standardized system that combines software and hardware controls to create a platform-dependent environment. ${ }^{153}$ It creates an

148. Kathleen M. Sullivan, The Justice of Rules and Standards, 106 HARv. L. Rev. 22 (1992).

149. Id. at 58 .

150. Burk \& Cohen, supra note 14 , at 56 .

151. See Gates, supra note 84 , at 651 ("Standards must be narrowly tailored to advance a legitimate procompetitive goal."); David A. Balto, Standard Setting in a Network Economy, Address at the Cutting Edge Antitrust Law Seminars International (Feb. 17, 2000) (transcript available at http://www.ftc.gov/speeches/other/standardsetting.htm\#N_8_(last visited Mar. 25, 2004)).

152. Thus far, Microsoft has obtained approval for two patents (Digital Rights Management Operating System, No. 6,330,670 and Loading and Identifying a Digital Rights Management Operating System, No. 6,327,652) that contain many of the basic elements of a secure operating system. See Microsoft Palladium Next Generation Secure Computing Base, at www.epic.org/privacy/consumer/ microsft/palladium.html.

153. Platform technology refers to software products that depend for their operation on basic data communication infrastructure, such as in cyberspace. See, e.g., Daniel Benoliel, supra note 6, at $1307-$ 09 (for the context of cyberspace); Chien-fu Chou \& Oz Shy, Partial Compatibility and Supporting 
unprecedented level of control over private information flows of its users by tracking information allocation and overinclusively licensing this operating system to its customers.

The level of precision is also influenced by the dcgree of nonintuitiveness. ${ }^{154}$ As broad, general legal commands, standards are less intuitive than rules in their applicability. Potential violators write off the cost of punishment for a violation by the low probability that they will be caught and by the even lowcr additional probability that the law will apply to their conduct. $^{155}$ The imprecise nature of standards reduces these probabilities, thereby lowering the command's deterrent effect. ${ }^{156}$ Furthermore, the vagueness of a standard actually creates a risk that legitimate conduct will be found to violate it. ${ }^{157}$ In the case of bright-line rules, on the other hand, a bad actor is allowed to engage in socially unproductive behavior only until he reaches the bright line. ${ }^{158}$

With the collapse of the deterrence function into the early promulgation phase of technological standards, the analysis of the degree of intuitiveness seems to be less relevant. In the case of technological standards, it is possible to indicate the exact coverage of the standard prior to design, for example by stating that a digital file is subject to a policy of "copy never," "copy once," or "copy free." Also, the probability that the law will apply to ccrtain conduct it is meant to address increases almost to one, subject, howcver, to the possibility that the technological standard might be illegally hacked or circumvented. ${ }^{159}$ Similarly, technological standards dramatically decrease the risk that legitimate conduct will be incorrectly considered a violation due to the vagueness of the command. Even more than with legal rules, technological standards create a substantive increase in the additional probability that the law will be held applicable to conduct, increasing also their overall degree of precision.

The third factor affected by a command's precision is the logical structure of the command. Rules are structured to allow their use to be not only clear, but at times systematic. In such cases, they apply to a particular case through a deductive form of reasoning that is, in their highest level of formality, almost mechanical. ${ }^{160}$ In contrast with standards, optimal rules in

Services, 41 ECON. LETTERS 193-97 (1993); Jeffrey Church \& Neil Gandal, Complementary Network Externalities and Technological Adoption, 11 INTL. J. INDUS. ORG. 239-60 (1993) (for the economic theory).

154. PoSNER, supra note 144 , at 591-93.

155. Id.

156. Id. at 591 .

157. Id.

158. See Kennedy, supra note 21 , at 1773-74

159. To illustrate, some watermarking technology allows the user to make first generation copies but prevents all further copying. EC Digital Rights Working Paper, supra note 58, at 19.

160. Sullivan, supra note 148 , at 58 and n.232. However, legal reasoning is now rarely equated with pure logic, so this may be something of an overstatcment. On the development of nineteenth 
fact can be designed to capture the background principle or policy and then operate with little ex post interpretation, independently of subjective or biased evaluations. ${ }^{161}$ The inner logic of such rules is a syllogism ${ }^{162}$; they can be seen as a logical proof consisting of three statements. The first two statements contain known or given propositions: (1) a major premise (e.g., "all the listed forms of copyright uses are excludable rights and the property of their lawful owner") and (2) a minor premise (e.g., "any use of these excludable rights requires the permission of their lawful owner"). These two propositions partially overlap in some fashion, leading to a deduced or proven conclusive third statement ("all listed forms of copyright uses need the permission of their lawful owner"). In bare-bones logic this is stated as: if $\mathrm{A}$ implies $\mathrm{B}$, and $\mathrm{B}$ implies $\mathrm{C}$, then $\mathrm{A}$ implies C. ${ }^{163}$

Technological standards can be designed to function similarly, within the limits of these commands' deductive possibilities. Technological standards can now process increasing amounts of data. As self-executing commands, they can use the set of parameters and alternative architectures best suited for a given scenario in a syllogistic fashion. In that way technological standards can be said to function similarly to rules.

Each of these three indicators for the increasing degree of precisionthe variable degree of over- and underinclusiveness, their variable degree of nonintuiveness, and the constant indicator for their syllogistic reasoning-indicate a close analogy between rules and technological standards.

\section{The Time Measurement: The Collapse of Optimal Lawmaking Back into Ex Ante Promulgation}

Fundamental to the law and economics analysis of optimal lawmaking is a concern regarding the optimal timing of a command's cost evaluation. The two main regulatory approaches may be ex ante in nature as they may apply before, or at least independently of, the occurrence of harm. Alternatively, they may be ex post in nature, triggered only by the occurrence of harm. As explained earlier, standards tend to have lower initial promulgation costs but higher enforcement costs relative to rules. ${ }^{164}$ As Kaplow theorizes, rules are typically more costly to promulgate than standards because rules involve ex ante determinations of the law's content. In contrast,

century Anglo-American jurisprudence regarding legal reasoning as a species of pure deductive logic, into its current reconciliation with value judgment jurisprudence, see Wesley Newcomb Hohfeld, Some Fundamental Legal Conceptions as Applied in Judicial Reasoning, 23 YALE L.J. 16 (1913).

161. Sullivan, supra note 148 , at 58.

162. See Steven J. Burton, An Introduction to Law and Legal Reasoning 41-50 (1985); Eveline T. Feteris, Fundamentals of Legal Argumentation 29 (1999); Posner, supra note 74, at 38-39.

163. Symbolic logic states it as: If $A \Rightarrow B$; and $B \Rightarrow C$; then $A \Rightarrow C$. Note, however, that this does not prove that the converse is true (if you establish $\mathrm{C}, \mathrm{A}$ need not also be true).

164. Kaplow, supra note 21 , at 562-63. 
standards are more costly for enforcement authorities to apply or legal advisors to predict due to the ex post requirement of determining the standard's content. ${ }^{165}$ For example, a rule may require an advance determination of what constitutes permissible driving speed in urban roads, while a standard may require leaving both specification of what speed is permissible and other factual issues for the adjudicator. Thus, a standard might prohibit reckless driving at an excessive speed on urban roads, leaving only factual issues for the adjudicator. ${ }^{166}$ Ultimately, where standards are efficiently utilized during enforcement, the value of rules would be smaller and it would be inefficient to expend the greater cost of designing rules.

Regulating at the proper time may prevent irreversible losses and may provide several benefits that, to some degree, offset the sunk cost of legal intervention. For example, a technological standard might prevent the revelation of data that could identify a user. Once the user is identified, an irreversible loss of privacy has occurred. Where the expected value of the law fluctuates over time, it is more valuable to use legal standards since their delayed application would prevent inefficient results. The opposite is true for rulemaking. To generalize, the optimal value of standard setting increases in correlation to three factors: (1) the degree of sunk promulgation costs, (2) the level of uncertainty in the regulated environment or the variance of the expected benefits from legal intervention, and (3) the increase in the value of standard setting in correlation to the expected rate of growth in the value of the law, such as when the law becomes more imperative over time. In accordance with this framework, the value of rulemaking decreases as these criteria increase.

This analysis does not, however, apply adequately to technological standards. This is because standardized technology collapses the optimal lawmaking analysis into the promulgation phase since technological standards marginalize enforcement costs. Consequently, when considering the timing of a legal command, technological standards are most comparable to legal rules because they are interpreted ex post and generally retain greater elements of ambiguity than technological standards, which are easier to apply ex ante in a fully quantitative manner. This is true to such an extent that what has traditionally been viewed as a separate later enforcement phase of rulemaking should, with regard to technological standards, be considered part of the promulgation cost structure of optimal lawmaking.

First, not only have the costs of on-line monitoring, identifying and executing enforcement been marginalized, but the costs are actually incurred ex ante in the promulgation or development phase of a technological

165. Id.

166. Id. at 559-60. 
standard. Moreover, to the extent that there are economies of scale in technological standards, extensive investments in promulgation activities, including addressing early enforcement concerns, may be substantial. ${ }^{167}$ Conceptually, the latter observation is not qualitatively different than that of the physical world and instead only accelerates these economies of scale quantitatively: according to which economies of scale in information acquisition, either in network environments or beyond it, prefer ex ante wholesale investments, given optimal lawmaking conditions. ${ }^{168}$

Both rulemaking and technological standardization are susceptible to uncertainty from future costs, benefits derived from the enforcement of a new legal command, and changes that may precipitate obsolescence in the designed command. However, with technological standards, standard setters can estimate many of these factors during design, since they define the standard's value measurements themselves. Consequently, in theory, in this new technological environment there are typically few advantages to delaying cost investments in the hope that information will be easier to acquire at a later time once individuals act or cases are adjudicated. As a result, costs related to uncertainty and irreversibility of ex post enforcement can be seen as integral to the ex ante promulgation cost structure and are not constrained by the value of waiting.

In network environments, the level of an individual's conformity to technological standards - the underlying litmus test of optimal lawmaking-is embedded in the initial decision to use the technology. This overrides the traditional social benefit of reducing learning costs, including the costs of obtaining legal advice by risk averse individuals. Consequently, technological standards have the advantage of highly predictable and monitored compliance without a direct or hierarchical binding relation to the legal framework with which they operate. The increased compliance and low cost of enforcement of technological standards makes them more comparable to legal rules than standards.

\section{III}

Legal Process Constrictions: Exogenous Institutional Costs

\section{A. Introduction}

The choice between rules and standards depends not only on the internal set of constraints on their design, but also on an external set of constraints from institutional administration costs. Consequently, it is necessary to consider the administrative institutional costs of the legal process that exist beyond the production process. ${ }^{169}$

167. Id. at 587 .

168. Id.

169. On the synthesis between the law and economics production cost structure analysis and the legal process movement, see, for example, Edward L. Rubin, The New Legal Process, the Synthesis of 
Optimal lawmaking theory suggests that legal standards decentralize decision making by entrusting greater decision making power to delegated agents, particularly government agencies and judges. ${ }^{170}$ Rules, in contrast, may involve centralized decision making. ${ }^{171}$ There are three conditions that favor centralized rulemaking. First, dispersion of harm reduces the effectiveness of decentralized control of risk since centralized lawmaking is better at identifying the sources and size of disperse harms and at controlling the harm. ${ }^{172}$ When the size of the harm to each individual is small, the harmed individual has little incentive to bring suit, at least when the option of class action is unavailable. ${ }^{173}$ This is the case in cyberspace since there is dispersion of harm based on a network effect among the users from DRM-enabled devices. Second, where a centralized social authority will be expected to possess or be better able to acquire superior information concerning risk or the occurrence of harm, a centralized lawmaking approach should prevail. ${ }^{174}$ This rationale is less applicable to technological standards in cyberspace. Third, centralization is preferable because it requires decision makers to act consistently, reducing the risk of arbitrariness or bias by delegated officials. ${ }^{175}$ Thus, centralized rulemaking is said to facilitate the social control by decision makers. ${ }^{176}$ Consequently, when the risk of error in adjudication ex post is high, ex ante centralization is optimal because it shifts the rulemaking function from the private to the public sector. ${ }^{177}$ In network environments like the lnternet, however, "technical standards" are bound to remain institutionally autonomous and decentralized, since today's technology may limit the ability of

Discourse, and the Microanalysis of Institutions, 109 HARV. L. REV. 1393, 1394, 1411-13, 1425-37 (1996). See also James G. March \& Johan P. Olsen, Rediscovering Institutions: The Organizational Basis of Politics 1-2, 16-19 (1989); Paul J. DiMaggio \& Walter W. Powell, Introduction, in ThE NEW Institutionalism in ORganizational ANALYSIS 1, 11-15 (Walter W. Powell \& Paul J. DiMaggio eds., 1991); Neil K. Komesar, Exploring the Darkness: Law, Economics, and Institutional Choice, 1997 WIS. L. REv. 465, 466-471 (1997).

170. See, e.g., Steven Shavell, Economic Analysis of Accident Law 283-84 (1987); Ehrlich \& Posner, supra note 144, at 267 (focusing on the centralization of rules). A decentralized lawmaking approach is privatized in the sense that the application of legal commands relies mainly on private citizens, namely victims and their lawyers. In contrast, however, a decentralized policy may be publicly enforced and is then known as administrative regulation. Decentralized policies rely much more on public officials (the staff of regulatory agencies) and generally try to prevent ex ante injuries from occurring rather than compensating for them ex post. See PoSNER, supra note 144, at 401.

171. Ehrlich \& Posner, supra note 4, at 267.

172. Id.; POSNER, supra note 144 , at 402 .

173. See SHAVELL, supra note 170 , at 283 .

174. Id.; POSNER, supra note 144 , at 403.

175. See Sullivan, supra note 69, at 63-65; POSNER, supra note 144, at 402-03; Ehrlich \& Posner, supra note 4 , at 267.

176. Id.; POSNER, supra note 144, at 402-03; Schäfer, supra note 128 (measuring human capital in law making as an exogenous effect to predict level of precision). Such control over lawmaking is also largely justified due to its implementation by a collective process or a representative body which takes into account social interests. See, e.g., Radin, supra note 10, at 1137-38.

177. See, e.g., Ehrlich \& Posner, supra note 4, at 267; SHAVELL, supra note 170, at 283-284. 
governments to program and design software-based regulation efficiently. This deprives technological standards of the advantages of centralization traditionally captured by legal rules and justifies further enhancement of a checks and balances approach to de facto technological standardization.

With the commercialization of the Intemet in the mid-1990s, consumer-oriented de facto standard setters established a solid hegemony over the technological standardization of the Internet. This shift was ultimately reflected in the commercialization of code writing. ${ }^{178}$ Standardization in network environments is now very closely related to the decentralized commercial decision making in traditional industrial companies. ${ }^{179}$ With technical standards, the choices made by these decentralized institutions largely complied with traditional law and economics analysis. However, the new generation of technological standards have moved beyond this analysis since they behave like rules but continue to be decentralized. Technological standardization is dominated by informal standard setting institutions, either individual entities or particular groups such as nonprofit organizations or consortia, ${ }^{180}$ which operate outside the governmental framework and standardize autonomously. ${ }^{181}$

For several economical and political reasons relating to the commodification of technological standards, the decentralized nature of technical standards is likely irreversible. ${ }^{182}$ First, in network environments rapid technological developments generally outpace the rate of slow bureaucratic decision making. ${ }^{183}$ Consequently, today's adjudicative evaluation may easily pertain to yesterday's technologies, and centralized technological standards may become anachronistic and inefficient. While decentralized standard setters may replace an inefficient technological standard by competitive technological "leapfrogging" over an uncompetitive technological

178. LeSsig, supra note 5, at 52; Yochai Benkler, Net Regulation: Taking Stock and Looking Forward, 71 U. CoLO. L. REv. 1203, 1233 (2000).

179. See, e.g., Mark A. Lemley \& David McGowan, Could Java Change Everything? The Competitive Propriety of a Proprietary Standard, 520 PLI/PAT 453, 471, 475 at n.52 and accompanying text (1998) (applying this observation to the separate product evaluation of the Windows 95 operating system and respective browser by the Antitrust Division).

180. For an introductory description of consortia, see Roy Rada, Consensus Versus Speed, in Information Technology Standards and Standardization: A Global Perspective, supra note 79 , at 19, 30-31. For a description of gray standardization institutions, see, e.g., Egyedi, supra note 99 , at 54-55.

181. CARGILL, supra note 3, at 117-31, 255-61, 275-96 (focusing on consortias, the government, and formal industry standardization organizations); Mark A. Lemley, Antitrust and the Internet Standardization Problem, 28 ConN. L. REv. 1041 (1996) (focusing on the government, industry players, and de facto standards); Lemley, supra note 5, at 747; Bob Toth, Putting the U.S. Standardization System into Perspective, 4 STANDARDVIEW 169 (1996) (reviewing the preeminent organizations in the United States).

182. See, Daniel Benoliel, supra notc 6, at 1323-26.

183. Breyer, supra note 33 , at 106; Martin C. Libicki, INFormation TeChnology STANDARDS: QUEST FOR THE COMMON BYTE 354 (1995). 
standard, there are typically fewer guarantees that centralized governments will or could do the same.

Second, in situations like technological standardization, it may be impractical and overly expensive to follow the actions of single regulators. For this reason, technological research and development joint ventures are largely essential. ${ }^{184}$ Third, once centralized production patterns are adopted, they acquire a taken-for-granted quality and are not easily dismissed or changed. ${ }^{185}$ In cyberspace, however, technological revision is constant and product life cycles for each technological standard are notably shorter. ${ }^{186}$ Fourth, a global economy has emerged in which neither the United States, nor any other single government, will always be able to play the predominant role in setting standards. ${ }^{187}$ Thus, national, centralized development of technological standards is replaced by international, decentralized cooperation between de facto standardization organizations.

Fifth, as noted in the literature on public choice theory, centralized regulatory bodies in a position to manipulate the outcomes of market competition are highly disposed to "capture" by private entities with an interest in the outcome. ${ }^{188}$ This is demonstrated by the high success of copyrightdependent industries in using legislative capture to acquire broad legal protection for rights management systems. Aftcr almost three years of lobbying in both Congress and international treaty proceedings, the copyright industries were rewarded with Title I of the Digital Millennium Copyright Act (DMCA), which bans tampering with or circumventing technological standard systems and prohibits the manufacture, distribution, and importation of circumvention tools. ${ }^{189}$ Such practices happen both in the legal design and technological standard setting. ${ }^{190}$ In a technological setting,

184. See Brown, supra note 91 , at 932 ("Cooperation-particularly with respect to interface standards and similar issues-may represent the logical way to further research and development objectives in this arca.").

185. MaRCH \& OLSEN, supra note 169, at 52.

186. CARGILL, supra note 3, at 170-74.

187. See, e.g., Linda Garcia, A New Role for Government in Standard Setting?, I STANDaRdVIEW 2, 5 (1993) (suggesting that in the globalized era, the influence of the Unitcd States has decreased substantially in determining the character of international standards institutions).

188. See, e.g., In re Dell Computer Corp., 121 F.T.C. 616, 1996 FTC LEXIS 291, *23 (1996) (Comm'r. Azcuenaga, dissenting) (describing capture of the standards-setting process by a patent holder); Janicc M. Mueller, Patent Misuse Through the Capture of Industry Standards, 17 BerkelEY TECH. L.J. 623, 628, 637-47 (2002) (describing different practices of capture of an industry standard by a firm holding patent rights in the technical subject matter of that standard).

189. Digital Millennium Copyright Act of 1998, Pub. L. No. 105-304, 112 Stat. 2860 (1998) (codified as amended at scattered scctions of 17 U.S.C.). The DMCA's anti-circumvention device provisions exclude devices that have some other commercially significant purpose or use. Id. $\S$ 1201(a)(2), (b)(1). In addition, the DMCA also empowers the Librarian of Congress, in consultation with the Register of Copyrights, to evaluate the impact of the circumvention ban on traditional fair use practiccs and, if neccssary, to issue rules excusing certain users of certain categories of works from the ban. See id. $\$ 1201$ (a)(1)(B)-(D).

190. See Radin, supra note 10, at 1138 . 
capture may occur when, for example, a private entity cooperates in the promulgation of a standard requiring potential users of the standardized technology to license the patent before its use, only to be later revealed as the claimant of a pending patent. ${ }^{191}$ Thus, there is no guarantee that a centralized, governmental standard setting body will act efficiently in the public interest, even when it is possible for a government agency to discern what the public interest is.

Nevertheless, when technological standards behave like legal rules, as described above, traditional law and economics theory suggests that they should also be designed through centralized institutions. However, decentralized institutions are more efficient in regulating technological standards, resulting in a democratic vacuum in privatized rulemaking.

\section{B. Decentralized Evasion of Law: Risks and Challenges}

In theory, formal political institutions, primarily industry standardization organizations such as the International Organization for Standardization (ISO) and the IETF, could successfully fill the democratic vacuum created by the decentralized design of technological standards. Formal industry standardization organizations should have the task of legitimizing choices made by decentralized standard setters. These organizations could ensure that relevant interests are represented and provide an appropriate level of control over decentralized development of standards. ${ }^{192}$ These elements define the role of formal standard setting organizations as guardians of de facto standardization processes and are already present in standardization ideology. ${ }^{193}$

In practice, however, such a system of checks and balances is not yet fully operational. There is no official test in the United States for ascertaining whether a standardization organization is a formal or informal private standard developer. ${ }^{194}$ Moreover, the demarcation between the two is empirically vague. No experiments have been conducted on competitive selfregulation, there is no real market for the control of standard setters, and there is no easy means of discharging incompetent administrators, even by

191. Id. at 1138 n.38 (citing Michael J. Schallop, The IPR Paradox: Leveraging Intellectual Property Rights to Encourage Interoperability in the Network Computing Age, AM. INTELL. Prop. L. Ass'N Q.J., Summer 2000, at 195, 283-84 (discussing standard manipulation by companics that have patents pending)).

192. Cf. MARCH \& OLSEN, supra note 169 , at 50-52 (for regulatory experience that predated cyberspace).

193. See, e.g., Louis G. Tornatzky et al., The Processes of Technological Innovation $41-42$ (1990).

194. In the United States, the American National Standards Institute (ANSI) is the organization to which alleged formal standard developers may apply in request to be accredited as formal standard setting organizations. Thus far, this procedure is nonbinding and voluntary and does not necessarily indicate the precise institutional state of affairs in the technological standardization community. See http://www.ansi.org/about_ansi/introduction/introduction.aspx?menuid=1. 
the principals (politicians and citizens). ${ }^{195}$ When the difficulty of controlling decentralized standard setters is added to the as yet unchallenged automated enforcement of technological standards and the social losses from the inability to centralize technological design, decentralized standard setting may encourage private standard setters to evade laws like the public access doctrine of fair use. ${ }^{196}$

\section{Broadcast Flag System Technology: A Case against Decentralized Manipulation of Optimal Rulemaking}

The promulgation of technological standards like DRM is resulting in a situation in which privately controlled misallocation of rights to information is tolerated and facilitated by public lawmakers. The forthcoming introduction of unencrypted digital television broadcasting provides an illustration of this problem. The FCC has recently mandated the nationwide introduction of digital television broadcasting by $2006 .{ }^{197}$ The treatment given to the copy protection method proposed for digital television broadcasts is known as the "Broadcast Flag System." In response to the FCC ruling, Ernest Hollings (D-SC) introduced a bill that would have required new consumer electronics products utilizing the digital broadcast system to include DRM technology. ${ }^{198}$ The Hollings bill ${ }^{199}$ would have required digital media devices to provide "effective security for copyrighted works" through technological standards, which the legislation referred to as security systems standards. ${ }^{200}$ More specifically, the technological standard would require DRM-enabled devices to recognize and respond to broadcast flags included in digital TV broadcasts. The flags would designate whether a particular broadcast could be redistributed outside the recipient's home. ${ }^{201}$

195. See, e.g., Joseph Farrell \& Garth Saloner, Competition, Compatibility and Standards: The Economics of Horses, Penguins and Lemmings, in Product Standardization and Competitive STRATEgy 5 (H. Landis Gabel ed., 1987).

196. Burk \& Cohen, supra note 14 , at 51.

197. See In the Matter of Advanced Television Systems, MM Docket No. 87-268, 1997 FCC LEX1S 2960 (FCC 1997), available at http:/www.fcc.gov/Bureaus/Engineering_Technology/Orders/ 1997/fcc97115.html (last visited Mar. 25, 2004).

198. S. 2048, 107th Cong. (2002). The legislation in question is referred to as the Security Systems Standards and Certification Act (SSSCA) and the Consumer Broadband and Digital Television Promotion Act (CBDTPA). See http://thomas.loc.gov/cgi-bin/query/z?c107:S.2048: (last visited Mar. $25,2004)$. The Hollings bill died in a committee last year, but it still may be reintroduced.

199. S. 2048, 107th Cong. (2002). The 107th Congress adjourned without voting or acting on the Hollings Bill. Nevertheless, the effeetive date of nationwide digital TV broadeasting is independent of the bill's status and is not delayed. $l d$.

200. Essentially consistent with the formal U.S. policy on the private sector's mandate over technological standardization, section 104 states that the private sector has twelve months to agree on a technological security standard or the Secretary of Commerce will intervene. If an agreement is reached, the secretary will turn the standard into a binding regulation. S. 2048, 107th Cong. (2002).

201. In the Matter of Digital Broadcast Copy Protection, Joint Comments of the Motion Picture Association of Ameriea, available at http://mpaa.org/press/MPAA_Comments_02-230.pdf (last visited Mar. 25, 2004) [hereinafter Joint Comments]. 
At around the same time, the FCC issued a notice of proposed rulemaking, inviting comments on whether it should mandate the integration of DRM copy protection technology into television receivers and other consumer electronics devices like digital television recorders. ${ }^{202}$

Underlying both the legislative and administrative initiatives is a response to the default allocation of the high promulgation costs of DRM standards. Thus far, DRM devices are more costly to design than they are worth to the producers of digital devices who would be required to install them. ${ }^{203}$ Consequently, device manufacturers either do not install them or install devices of low quality that are potentially ineffective. Moreover, content industries have little incentive to subsidize DRM promulgation costs, and the imposition of such a subsidy is an indirect form of economic blackmail at the expense of content industries, made to guarantee their data protection of preferences. As a result of this deadlock, the strategy of the content industries has been to promote centralized legislation, such as the Hollings bill, which would mandate DRM standards. In the case of the Hollings bill in particular, a coalition comprised of private copyright owners, broadcasters and entertainment industry unions is urging the FCC to adopt a rule that would support their private interests and would be susceptible to capture by these industries.

As might be expected from a piece of legislation that raises concerns of legislative capture, the broadcast flag system is an over inclusive command. In other words, content providers are trying to reallocate permanently public access rights to digitized content. They allow access only if the recipient's computer or other device (e.g., mobile devices) incorporates hardware and software meeting security specifications approved by the content providers themselves. ${ }^{204}$ Broadcast flags do not encrypt any digital TV signals. The content protections work only if devices that receive and process digital broadcasts are designed to recognize whether particular signals may be redistributed outside the recipient's home and only if those devices prevent redistribution when redistribution is not authorized by the signal's broadcast flag. Consequently, decentralized content providers are also privatizing the enforcement authority with strict technological standards, under which individuals would be banned from access and use of particular digital content in a way that might override legitimate fair use. In balance, the FCC should now act to check and balance this predisposed

202. In the Matter of Digital Broadeast Copy Protection, MB Docket No. 02-230 (FCC 2002), available at http:/hraunfoss.fcc.gov/edocs_public/attachmatch/FCC-02-231A1.pdf (last visited Mar. $25,2004)$.

203. One of the most current examples is the weak CSS encryption standardized technology that DVD player makers agreed to implement under duress from film studios. See DeCSS Central, available at http://web.Iemuria.org/DeCSS/decss.htmI (last visited June I5, 2004).

204. See, e.g., Felix von Leitner on the OVO CSS craek, available at http://www.tbtf.com/ resource/css-Leitner.htmI (last visited June I 5, 2004). 
decentralized sway over the rulemaking process of these technological "standards."

\section{IV}

\section{SUMMARY AND CONCLUSIONS}

Technological standards, which directly regulate behavior, are a different category of standards than technical standards, which only regulate form. In terms of optimal lawmaking analysis, technological standards are closely related to legal rules. For example, both substantive rules and technological standards influence user behavior directly. As technological standards' influence on behavior increases, they will increase in similarity to legal rules. Rules are best promulgated by centralized institutions, particularly public, governmental institutions. In network environments such as the Internet, however, centralized regulation is unable to keep pace with the dynamic commercialized nature of technology. Thus, the technique commonly known as technological standardization is still best kept decentralized.

In essence, two opposing developments are creating a regulative anomaly. On the one hand, technological standards are increasingly characterized as legal rules, which are best regulated centrally. At the same time, however, decentralized regulation is gaining institutional dominance of the technological standard setting. Because of the nature of technology, these developments seem to be irreversible. Notwithstanding these institutional constraints in network environments, I wish to recommend to policy makers, primarily the FCC, a rule oriented interpretative approach, backed by an adapted system of checks and balances, in order to capture some of the benefits of centralized rulemaking.

One initiative in this spirit is a bill called the Consumers, Schools, and Libraries Digital Rights Management Awareness Act of 2003, introduced by Sam Brownback (R-KS), ${ }^{205}$ which largely precludes the FCC from mandating that consumer electronics, computer hardware, telecommunications networks, and any other technology that facilitates the use of digital media products, such as movies, music, or software, be built to respond to particular digital rights management technologies. ${ }^{206}$ If such a bill is adopted, the FCC, in fact, will become another balancing institution involved in decentralized technological standardization.

205. See, S. 1621, 108th Cong. (2003), available at http://www.eff.org/IP/DRM/ 20030916_brownback_bill.pdf (last visited Mar. 26, 2004).

206. The bill also limits the exceptions to mandating the inclusion of access or redistribution of control technologies to eases (1) pursuant to a grant of specific and clear authority from Congress to assure a result in its regulations and (2) when the mandate is derived from voluntary private sector efforts that protect the legal, reasonable, and customary practices of end-users. Id. at Sec. $2(1)$. 
Moreover, the task of formal political institutions should be to confirm the legitimacy of choices made by de facto standard setters by ensuring that all interested parties are involved and by exercising an appropriate control structure over decentralized standard setting. ${ }^{207}$ In the absence of successful efforts from de facto standard setters, the FCC could be required to ensure that consumers are provided with adequate information with respect to the existence of access and redistribution control technologies. ${ }^{208}$ The regulatory anomaly described herein both calls for further advancement toward the use of formal industry standardization organizations backed by FCC supervision, and justifies the progress made thus far. To prevent the evasion of law by decentralized standard setters, the FCC and theoreticians alike must first recognize this regulatory anomaly and then minimize its effects.

207. See MARCH \& OLSEN, supra note 169 , at 50-52.

208. See, e.g., S. 1621, 108th Cong. (2003), supra note 205. 